University of Nebraska - Lincoln

DigitalCommons@University of Nebraska - Lincoln

Fighting the forces of gravity - Seapower and maritime trade between the 18th and 20th centuries

Ahmed S. Rahman

United States Naval Academy, rahman@usna.edu

Follow this and additional works at: https://digitalcommons.unl.edu/usnavyresearch

Rahman, Ahmed S., "Fighting the forces of gravity - Seapower and maritime trade between the 18th and 20th centuries" (2010). U.S. Navy Research. 41.

https://digitalcommons.unl.edu/usnavyresearch/41

This Article is brought to you for free and open access by the U.S. Department of Defense at DigitalCommons@University of Nebraska - Lincoln. It has been accepted for inclusion in U.S. Navy Research by an authorized administrator of DigitalCommons@University of Nebraska - Lincoln. 


\title{
Fighting the forces of gravity - Seapower and maritime trade between the 18th and 20th centuries
}

\author{
Ahmed S. Rahman \\ Department of Economics, United States Naval Academy, 589 McNair Road, Annapolis, MD 21402, USA
}

\section{A R T I C L E I N F O}

\section{Article history:}

Received 16 January 2008

Available online 2 June 2009

Keywords:

Trade

War

Naval history

\begin{abstract}
A B S T R A C T
How have large naval powers affected international commerce in history? Using a panel gravity model, we investigate the interactions of wars, alliances, naval power and trade from the 18th to mid-20th centuries. Striking an alliance with a naval power helps a country's interstate commerce. Fighting a naval power on the other hand limits a country's interstate commerce. Further, we split this effect on trade between an extensive effect (effect on a country's trade when fighting a naval power) and an intensive effect (effect of that power gaining more naval strength). We conclude that the intensive effect is a powerful one - large navies have historically been destroyers of trade when mobilized to combat.
\end{abstract}

Published by Elsevier Inc.

\section{Introduction}

The aim of this paper is to address the general question: how have large naval powers affected international trade historically? Given the basic geography of the world - great masses of land separated by large bodies of water - the ability of one country to influence another, economically, politically, or militarily, has depended in large part on seapower. It seems natural then for economic historians to analyze the historic interactions of trade (a measure of economic influence) and naval power (a measure of military influence).

In this paper, we attempt to answer the question by interacting measures of naval power with measures of alliances and conflict. Controlling for other variables traditionally associated with international trade, we find a strong impact of large naval warships on trade volumes. Specifically, striking an alliance with a naval power helps a country's interstate commerce, while fighting a naval power hurts a country's interstate commerce. Further, this conclusion is robust to different measures of "naval power;" whether captured by the number of power warships utilized at the time, or by overall naval expenditures, naval fleets historically have altered the flows of international trade.

This work joins the ever-burgeoning group of papers on the applied economics of international trade. Empirically-minded trade economists have sought to assess the trade impacts of various economic disturbances and policy regimes by using some agreed-upon benchmark model. This benchmark has traditionally been the gravity model of trade, which controls for a variety of geographic, economic, and political factors. With such controls one can analyze the ceteris paribus effects of such things as exchange rate variability (Thursby and Thursby, 1987), preferential trade arrangements (Frankel et al., 1996), currency unions (Rose, 2000; Flandreau, 2000), gold standard adoption (López-Córdova and Meissner, 2003), and empire (Mitchener and Weidenmier, 2008).

\footnotetext{
th Many thanks to Ryan Brady, Greg Clark, Guillaume Daudin, Kerstin Enflo, Darell Glaser, Victoria Greenfield, Katherine Smith, Thomas Zak, and participants of the 7th Annual European Historical Economics Society Conference in Lund, Sweden, as well as two anonymous referees, for their helpful suggestions. Comments welcome at rahman@usna.edu.

E-mail address: rahman@usna.edu
} 
The effects of conflict on trade however have received much less attention among economists. Instead the conflict-trade relationship has been extensively analyzed by political scientists, and they have focused their attention to the reverse analysis - the effects of trade and other measures of international "connectivity" on the likelihood of conflict among countries (Barbieri, 2002; Barbieri and Jack, 1999; Oneal and Russett, 1997). Few papers have addressed the question of the quantitative impact of conflict itself (or its absence) on trade.

For those papers that do, the empirical results are mixed. Theoretically it seems natural that military conflict should reduce trade among adversaries, through trade embargoes, seizures, and other disruptions. This however has proven to be somewhat difficult to empirically verify. Pollins (1989), Bergeijk (1994), Mansfield and Bronson (1997), and Glick and Taylor (2008) estimate gravity models and find that conflict lowers trade. In contrast, Morrow et al. (1998), Mansfield and Pevehouse (2000), and Penubarti and Ward (2000) also utilize gravity models and find no statistically significant effects of conflict on trade.

There are, however, a number of defects with the above-cited literature. First and most importantly, these studies are typically plagued by endogeneity because they focus on trade among adversaries. The studies simultaneously analyze trade between countries $i$ and $j$ and conflict between $i$ and $j$; the obvious inter-linkages between these two variables severely complicates causal analysis. The result has been a kind of intellectual bifurcation - among the "internationalists," the political scientist states "trade promotes peace;" the economist avers "peace promotes trade." The primary direction of causality still remains unsettled.

Secondly, these studies do not account for the extent of the warring power's ability to damage trade. Fighting with a country that has little global reach or military might should scarcely influence international trade volumes. But intensive measures of conflict (how "powerful" is your foe?) are rarely used in the literature. Instead, extensive measures of conflict (do you have a foe?) are typically used to capture the effects of conflict on trade.

Finally, most studies use pooled, rather than panel, estimators that may not adequately control for omitted country- or pair-specific attributes, nor effectively distinguish between the effects of conflict on trade across country pairs and the effects over time (Glick and Taylor, 2008 is the exception).

To deal with these issues in the study of the effects of conflict on trade, we explore a new approach by focusing on third parties in this international system of commerce - sea powers. Social scientists and naval historians largely acknowledge the tremendous influence navies have had on international trade. That seapower has been used as a national defense strategy to protect one's own merchant trade and commercial interests remains fairly uncontroversial (see for example Lewis, 1959; Crowhurst, 1977; Harding, 1999). But the public good nature of seapower gives rise to a host of potential international externalities that may either help or harm the trade of other nations.

Thus following Glick and Taylor (2008) we use a gravity model with panel data utilizing country-pair fixed effects estimation, so that we control for any time-invariant country-pair characteristics. But rather than focus on trade and conflict between countries $i$ and $j$ simultaneously, we focus on trade between $i$ and $j$ and conflict between $i$ and $k$, where $k$ is some naval power. Concentrating attention on the spillover effects of third-party navies will give us another view of the causal effects of military expenditures on international trade. This third party approach is illustrated in Fig. 1.

Indeed, it may be argued that an extensive measure of conflict will be more prone to endogeneity problems than an intensive measure. The decision to go to war with a nation will arise from a host of international factors, possibly including trade and military strength. Trade however is unlikely to factor into a military power's decision to subsequently build up its military strength. Naval power $k$ will build up a strong navy for many reasons unrelated to trade between countries $i$ and $j$. Further, use of panel data approaches are more effective in dealing with endogeneity concerns than other techniques typically used in empirical gravity-model studies, such as instrumental-variable or control-function techniques (Baier and Bergstrand, 2007).

Fig. 2 diagrammatically represents some of these ideas. While most studies focus on the extensive effect of conflict between two counties on the trade between those two countries (dotted line), we focus on the effects of conflict between a

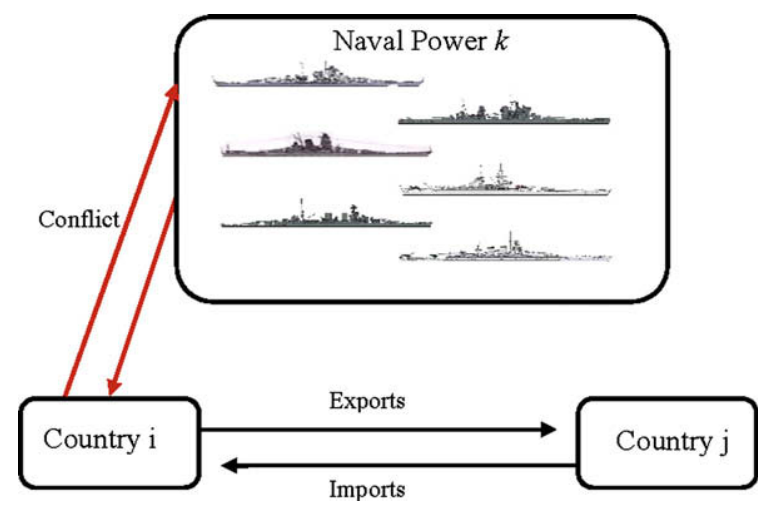

Fig. 1. Third-party approach to effects of naval conflict. 


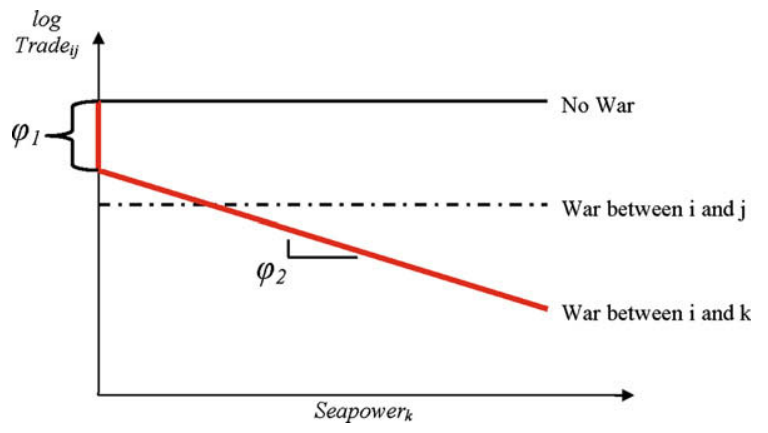

Fig. 2. Extensive and intensive margins.

trading country and a naval power (red line). Further, the total decrease in trade will be due not just to the conflict itself, but also the extent by which the naval power can damage trade. Thus the total adverse effect on trade between countries $i$ and $j$ is $\left(\phi_{1}+\phi_{2} *\right.$ Seapower $\left._{k}\right)$.

Because of the panel nature of this analysis, our study is thematic; most of the navalist literature on the other hand tends to be episodic. The downside to our approach is that we cannot break down the effects of individual battles, or determine the number of ships involved in each conflict, or even verify that a country's navy had any involvement in the conflict at all. ${ }^{1}$ As we will see, our measures of seapower do not measure naval forces engaged in explicit combat, only the naval capability to engage in combat. But what we lose in precision we make up for in breadth, by utilizing a wide panel of trade, navy and conflict data to draw general conclusions on the historic importance of naval power for international trade. This has heretofore never been attempted, although the general lessons that come out of such a study should be of interest to both naval and economic historians.

We should highlight that we are not attempting to quantify the total effects of naval power on inter-state commerce. Our far less ambitious project simply attempts to see whether variations in "protagonistic" and "antagonistic" naval powers can help explain variations in trade patterns. The fact that it seems to does not allow us to say anything about the net effects on trade. It does however tell us that fighting naval forces have hurt trade, and that friendly naval forces have helped it.

The rest of the paper proceeds as follows. Section 2 discusses some issues concerning the nature of seapower and the general empirical strategy. Section 3 looks on the 18th century case of English trade and highlights some of the pitfalls of a "naive" gravity approach. Section 4 presents the main empirical methodology and results for the 19th and 20th century case. Section 5 concludes.

\section{Seapower and trade}

\subsection{The Spillovers from large navies}

Have navies traditionally been strong forces of maritime trade destruction in the past? Or have they instead served to help facilitate the flow of international trade? This is a challenging question to address, in part because of the complicated interconnections between naval power and maritime trade. Understanding these interconnections requires to some extent an understanding of the objectives of any large navy. The historical strategic missions of the US navy, for example, can be categorized into four general groups: freedom of the seas (or 'sea control'), deterrence, forward presence, and power projection (Cutler, 2002). Efforts designed to promote freedom of the seas and to deter potential attacks might be considered forces that promote trade, particulary trade among the allies of the naval power. Projecting one's power or increasing one's presence internationally, on the other hand, may be thought of as potential hindrances to trade, particularly trade between countries hostile to the naval power.

As the focus of this study is on the spillover effects of naval power on international trade between other countries, we look to the possible ways that such power projections can indirectly effect international commerce, either positively or adversely. Adverse actions include guerre de course strategies, blockades and embargoes, and other less explicit forms of economic warfare. Such strategies are often designed to serve the trading links between the enemy and her allies or neutral countries, and in so doing, to reduce the level of military and civilian goods that are available to support her military endeavors. On the other hand, navies are also intended to protect one's own trade, and as such may indirectly bolster trade between fellow allied nations. While our conflict and alliance data will not distinguish between these various uses of naval power, we should understand that our measures will capture (and lump together) many of these tactics.

Perhaps the most explicit (and oldest) form of economic combat using naval forces is the strategy of guerre de course. Guerre de course (literally "war of race") refers to a naval strategy that is aimed at raiding and destroying the commerce

\footnotetext{
${ }^{1}$ For example, see Davis and Engerman (2006) for a fascinating account of specific naval blockades in history.
} 
of an enemy as a primary war strategy, as opposed to the traditional goal of acquiring command of the sea. This strategy has typically been used by smaller inferior naval powers whose own commerce may be threatened by a superior navy. The fledgling US navy pursued this tactic against Great Britain during the War of 1812, as did the French against Britain in the 19th and early 20th centuries, and the Germans against the allied powers in both world wars.

The decision of a naval power to pursue a guerre de course strategy has in the past come from a variety of factors. One potential motivation was to limit a rival nation's exports in order to increase one's own exports, echoing the traditional mercantilist view of a fixed global volume of trade. Thus commerce-raiding could be a way to both debilitate a foreign nation and enrich your own nation. The destruction of a rival's imports could also be a goal. Britain's dependence on overseas food supplies for example has forever tempted the French into the guerre de course stance, in the hopes that food shortages would foment social and labor unrest and thus weaken England militarily. Further, France's geographic proximity to England made this policy all the more tempting, as French ships could be easily placed in the North Sea, the Channel and the Atlantic where great volumes of British trade passed (Mahan, 1890). Beyond strategic and geographic considerations, technological changes have also shaped the decision to engage in commerce-raiding. For example, the use of steam technology made guerre de course more costly (as it allowed merchant ships, no longer dependent on the wind, greater leverage to deviate from their original trade routes), while the advent of torpedo boats and submarines made guerre de course more effective (as merchant ships became far more vulnerable to forms of nautical ambush).

These offensive uses of seapower can have serious consequences for international commerce, but sea-faring nations have always highlighted the defensive uses of this power to justify a robust navy in the first place. In contrast to the guerre de course strategy, a guerre d'escadre (literally "war of squadron") strategy involves command and control of the sea, the ultimate strategic ideal for the big navy and apparatus ostensibly designed for the defense of one's own trade. Large navies may escort and protect merchant ships in transit through convoys, to defend either against guerre de course or general piracy. Even during peacetime, a state with a global trading position will wish to assure itself of the ability to protect its trade from the very offensive actions noted above by other navies, as well as hostilities from third parties (such as terrorists or pirates). This requires protection of trade routes, choke points, and access to critical areas. In arguing for a strong navy, these needs are often cast in terms of protecting vital commodities, such as oil ${ }^{2}$ other times they are seen as a general requirement for protection of an entire trading system vulnerable to potential threats.

Thus the navalist literature seems to focus either on guerre de course strategies, performed by smaller war vessels and aimed at destroying an enemy's trade, and guerre d'escadre, performed by large war vessels and aimed at protecting one's own trade. A casual read of naval history elevates the grand warships as protectors of commerce and guardians of prosperity. The spoilers of trade in contrast were fiendish frigates and sneaky submarines, or worse still, privateers contracted by weaker naval powers ill-equipped to intercept enemy cargo vessels themselves. Alfred Mahan's grand vision of the "great white fleet" thus appears to be a nobel one, utterly consistent with the world of unprecedented commerce about which he was writing. ${ }^{3}$

But we would argue that large vessels can cause damage to maritime trade precisely because of their size and power. Of course it is true that history is rife with episodes of smaller war vessels conducting guerrilla raids on traders (French privateers during the Revolutionary/Napoleoninc Wars, German U-boats during World War I, etc.). But these raids were necessarily confined to trade routes close to the home country (both French privateers and German submarines focused their aggression on nearby England). For example, looking at the actual letters of marque issued by the English Court of Admiralty during the 18th century shows that British privateers operated mostly locally (Gathmann and Hillman, 2007). Only large ships of global reach have the potential to disrupt maritime commerce conducted on distant waters. As intercontinental trade rapidly grew throughout the 19th century, then, the potential damage to trade by large war vessels relative to small vessels grew as well.

Further, only large vessels have the ability to effectively blockade an enemy nation, perhaps the most commercially destructive action a navy can perform. For while guerre de course is a strategy of irritation, blockades and embargoes are policies aimed at utter strangulation, and these are ambitious methods employed by big navies. The typical aim is to reduce the enemy's ability to effectively carry out military operations; this can be accomplished for example by reducing imports of food, war munitions and other necessary commodities, or reducing exports to erode the enemy's capability to fund its war efforts (Brodie, 1944). Whatever the specific strategy, an effective blockade will dramatically cut the volume of commerce between an enemy and its trading partners.

There are also a variety of naval actions by large vessels that can have some (often ambiguous) impact on trade on a smaller scale. These include gunboat diplomacy, showing the flag, policing territorial waters, ensuring "good order," and enforcing treaty rights of passage. Often these actions involve nothing more than displaying one's fleet off a foreign country's coast. This can however create a subtle force of trade deterrence by hostile nations that may fear the confiscation of commerce. Or it can simply re-channel trade among bilateral pairs; for example it is conceivable that US gunboat diplomacy with China during the 19th and 20th centuries induced China to trade less with Japan in order to trade more with the US. Finally, a coun-

\footnotetext{
2 Today the United States spends a considerable amount defending oil supplies from the Middle East, for example.

3 The US had traditionally maintained a guerre de course navy throughout the 19th century. Yet with Teddy Roosevelt's view of naval expansion as an integral part of America's transformation into a world power and the navy as a positive instrument of national policy, the US transformed its 20th century fleet into one with a decidedly guerre d'escadre focus (McBride, 2000).
} 
try with an adversarial relationship with a naval power will not enjoy the international protection of that power, thus facing greater risks from piracy and other predatory acts which may damage their commercial interests.

The thing here to stress is that large war ships can influence the scope and direction of maritime trade between other countries in a number of ways. This will be more true in the 19th and 20th centuries context (when distant intercontinental trade became substantial) than the 18th century (when smaller war vessels performed the bulk of commerce raiding through guerre de course), although large naval ships may still exert positive or negative effects on trade even in earlier periods. Further, navies constructed for one thing are often charged to do something else - for example, vessels originally built to police the Pacific Ocean may suddenly be called upon to blockade a new enemy in the Atlantic. Indeed, when it comes to the effects of large navies on trade, ex ante strategies scarcely matter - a ship designed for guerre d'escadre can be just as effective in blocking trade (through blockades or general power projections) as ships designed explicitly for raiding commerce.

Thus large naval vessels can produce international spillover effects on the maritime activities of other countries. An ancient example is the Athenian Navy during the second Peloponnesian War (431 B.C.E. to 404 B.C.), which had become the largest and most powerful fleet ever known. This navy's provision of security along the Aegean Sea's trade routes was a public good susceptible to free-riding by other merchants (Neal, 1994). For our study of the 18-20th centuries, as conflicts and alliances spring up, existing navy ships can be used to hinder the trade of enemies or help the trade of allies. ${ }^{4}$ Irrespective of past strategic intent, the size of naval fleets or past expenditures on naval construction may serve as explanatory variables for current international trade and commerce.

\subsection{Empirical strategy}

We begin with the standard gravity model of international trade, which predicts bilateral trade flows based on the economic sizes of and distances between two countries. The basic theoretical model for trade between country $i$ and country $j$ takes the form of

$$
\text { Trade }_{i j}=C\left(\frac{Y_{i} Y_{j}}{\text { Dist }_{i j}}\right)
$$

where Trade $_{i j}$ is the bilateral trade flow between countries $i$ and $j, Y$ is each country's GDP, Dist ${ }_{i j}$ is the geographic distance between the two countries, and $C$ is a constant. To this basic setup has been added additional factors such as language relationships, tariff levels, contiguity, and colonial history. While these additional factors have been shown to explain trade patterns, they are often constant over time, and thus their effects cannot be gauged when using country-pair fixed effects estimation (as is our goal).

In analyzing the effects of shifting naval power on bilateral trade flows, we will amend (1) so that our new model is

$$
\text { Trade }_{i j}=C\left(\frac{Y_{i} Y_{j}}{\text { Dist }_{i j}}\right)\left(\frac{e^{\text {ProtagFleet }_{i j}}}{e^{\text {AntagFleet }_{i j}}}\right)
$$

where ProtagFleet ${ }_{i j}$ is a measure of the naval power of the "protagonistic fleet" and AntagFleet ${ }_{i j}$ is a measure of the naval power of the "antagonistic fleet." Conceptually, one should consider a protagnostic fleet to be the naval fleet of some country $k$ which happens to be either $i$ 's or $j$ 's ally. We would predict that the power or global reach of a "friendly" navy should be positively related to bilateral trade flows.

On the other hand, an antagonistic naval power can be considered a type of "iceberg cost" that increases the costs of transporting goods over seas, and thus lowers the total amount of a country's trade volume. A naval power becomes "antagonistic" when an international conflict erupts between this power and one or both trading partners. Let us define "naval war" or "naval conflict" as a situation where country $i$ and/or country $j$ is fighting a country with a navy with global reach. The primary purpose of this study is to analyze how this antagonistic fleet can damage a country's trade.

How might we actually measure the extent of this power? We next turn to addressing each of these questions.

\subsection{Measuring seapower}

In any study of naval strength at the country level, three general issues must be addressed - the appropriate measure of naval power within a country, the comparability of measures across countries, and the comparability of measures across time.

The first issue deals with the appropriate "size" of the navy - which ships should be deemed relevant to the study? Clearly the answer to this will depend on the nature of the study. For us, we are primarily concerned with ships that have "global reach" - that is, ships which can be sent to far off places, that can go on extended excursions, and that have sufficient warfare capability to damage the enemy. These vessels can be considered the international "strongarm" of the military, and thus be viewed as those ships able to affect international commerce. At any given time only a handful of naval powers had such capa-

\footnotetext{
${ }^{4}$ An nineteenth century example of this kind of free-riding would be the 1823 Monroe Doctrine, which declared the Western Hemisphere off limits to intervention by European powers and certainly helped bolster US commerce. Of course such a doctrine could only be sustained by the power of the allied Royal navy (Findlay and O'Rourke, 2007).
} 
bility. For example, the smaller navies at the turn of the 20th century (e.g. Italy, Austria, Spain, Turkey, Sweden, Brazil, etc.) were considered only coastal defense navies. While they certainly had the ability to defend and influence their own trade, they did not have the superpower status necessary to influence the bilateral trade of others. Indeed it is the superpower status of these navies that make them relevant as third-party factors. Hence we will focus only on ships with global reach.

The second issue deals with comparing naval strengths across countries. Again, looking only at superpower navies may help alleviate some of the concerns that come from naval heterogeneities, as all the superpowers were more or less at the cutting edge of naval technology. Of course we know this is not strictly true; for example, Portuguese ships in the 15th and 16th centuries (part of a global power navy at the time) tended to be much heavier than their English, Dutch, and French counterparts because they were built for the long route to India (Thomson, 1994). And the 19th century US navy closely followed but continually lagged behind its UK counterpart (McBride, 2000). But much as we do not expect huge technological differences today between Japan, German and the US in leading industries such as automobiles or food processing, ${ }^{5}$ we do not believe that ship design and effectiveness varied tremendously between those at the forefront of naval development; top naval constructors often scrutinized the designs of rival vessels in order to emulate them (McBride, 2000). Indeed, the top naval powers were actually hesitant to push innovation itself (which tended to devalue existing ships), opting instead to respond to innovation made by others (O'Brien, 2001). Thus patterns of naval development tended to follow across these countries quite closely.

This brings up the third and perhaps most thorny issue - naval technological growth. From the seventeenth century to the mid-19th century, the relevant global warship was the ship-of-the-line. The importance of these ships stemmed from the naval tactic known as the line-of-battle, where two columns of opposing ships would manoeuvre to maximize the number of broadside guns to bear. Since these engagements were almost invariably won by the heaviest ships carrying the most powerful guns, the natural growth of naval technology involved building the largest, most powerful sailing vessels possible. So naval strength before 1860 is easily measured as the number of ships-of-the-line with a minimum number of guns. ${ }^{6}$

But by 1860 these wooden ships-of-the-line were rendered naval dinosaurs by the development and gradual application of a variety of new weaponry, including explosive shells, armor-clad battleships, torpedoes, mines, and ramrods (apparently resurrected from the galley era). Thus by this time the Industrial Revolution had finally penetrated naval technology. Explosive shells - first used at the Battle of Sinope in the Crimean War - obsoleted wooden hulls; steam engines obsoleted sail technology. But the trial-and-error experimentation of the period 1859-90 hinders those bent on making direct comparisons across navies. No longer is the minimum-gun criteria applicable, but what should replace it? In contrast to the amazing stability of the wooden sailing-ship phase, the new ironclads (many of which were not ocean-going battleships despite occasional claims to the contrary) became obsolete very quickly. Iron plating gave way to steel ships, but at varying times in each navy's history. The confusion of the period is best summed up by Padfield (1972): "It is unnecessary to catalogue the incredible misdirections, false starts, unsightly and unhandy steam kettles, half submerged, double elliptical, rhinoceros-skinned misfits weighted down by huge turrets swaddling one or two ponderous barrel-like pieces, which marked the fearful adolescence of the ironclad."

Yet out of the haze a new global standard for global naval ships emerged by 1880 - the first-class battleship, once again capable of assuming a front-rank position in the fleet battle-line. The minimal threshold was no longer primarily in terms of the number of guns carried but rather in the range of these guns. The principal naval competitors increasingly built similar, if not identical, kinds of battleships, and use of internationally comparable ratings (i.e. first class, second class, third class) for battleships re-emerged in the 1880s.

But the reign of these ships was relatively short-lived due to the development of an even more advanced battleship type the Dreadnought. Inspired by the lessons of the Battle of Tsushima between Russia and Japan in 1905, where long range fire had decided the battle, the British commissioned the first Dreadnought in 1906. For a time pre-Dreadnought ships (with a main battery of four guns and a top speed of 18 knots) co-existed with Dreadnoughts (with 10 guns and a top speed of 21 knots). But the clear inferiority of the pre-Dreadnoughts render them as inappropriate measures of 'global power ships' after 1913. ${ }^{7}$ Luckily for comparatavists, the Dreadnoughts were usually treated as a relatively homogenous class of fighting ship despite their comparatively long reign (1906-1945).

Thus we see that our longitudinal study is frustrated by the use of different ships at different times. In contrast to the smoother escalation of the minimal number of guns that needed to be carried for front-line duties in earlier centuries, the changes in naval technology in the late 1850s, the early 1880s and 1906 practically forced the maritime powers of the time to start from scratch.

To deal with these complications, we turn to Modelski and Thompson (1988), who have amassed a collection of data from various sources to quantify the historical global reach of navies. Doggedly comparatavist, the study takes great pains to control for quality differences among the naval fleets wherever possible. From predominantly country-specific sources, the authors construct time series for ships-of-the-line, 19th century battleships, pre-Dreadnoughts, and Dreadnoughts, as well naval expenditures for six naval powers from 1816 to 1938 (measured in millions of 1913 £s). Figs. 3 and 4 plot out some of these measures.

Of course a more general solution to our discontinuity problem consists of merging ship counts with the more stable (in the comparative sense) indicator of naval expenditures. Although naval expenditures have the advantage of greater conti-

\footnotetext{
${ }^{5}$ Instead we tend to chalk up differences in production based on differences in efficiency, a different matter entirely.

${ }^{6}$ For our study, the minimum number of guns for ships-of-line between 1710 and 1860 is fifty, the standard necessary to be considered a global power vessel (Modelski and Thompson, 1988).

7 The comparative naval tables in Brassey's Annual Naval count only Dreadnoughts as ‘modern’ battleships after 1913.
} 

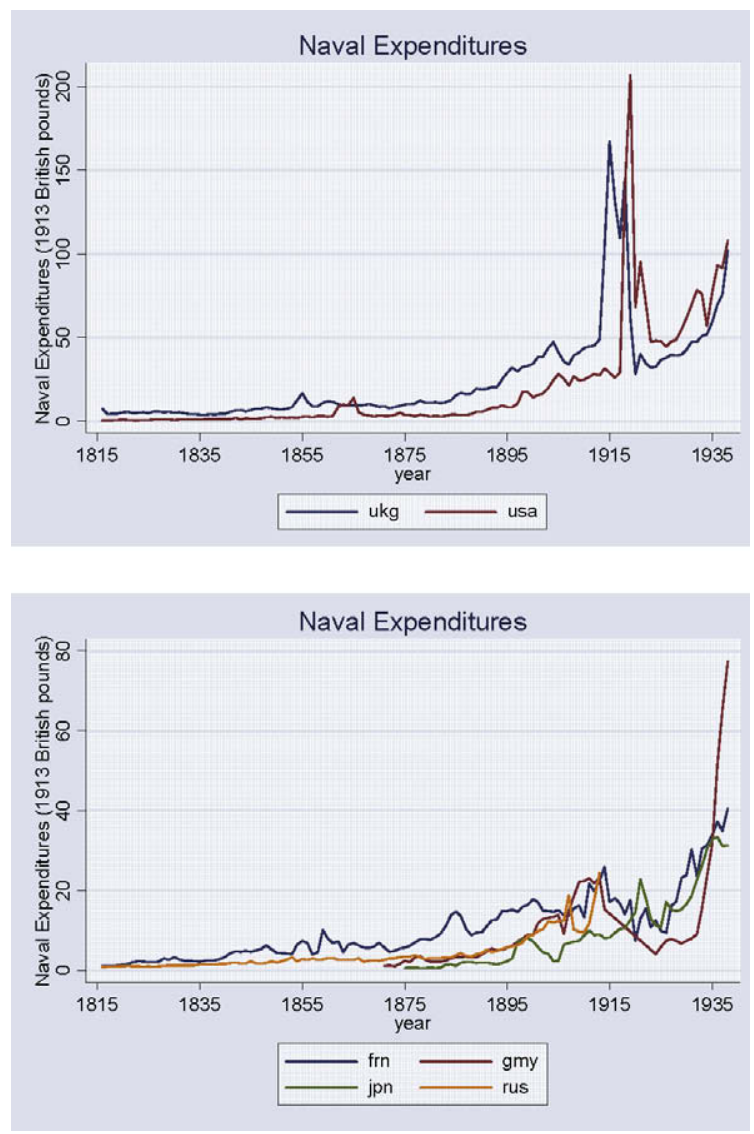

Fig. 3. Naval expenditure data from Modelski and Thompson (1988).

nuity, they possess too many limitations of comparability to rely upon them as an exclusive indicator of seapower. Hence we will use both expenditure and count data to measure seapower.

\section{A naive approach - the "Long 18th century}

In this section we turn to the "long" 18 th century (specifically, 1710-1822) to analyze the effects of naval strength on English trade. We also highlight the limitations of such an approach, motivating us to turn to a more general study in the next section.

\subsection{Empirical strategy}

From the late 17th century until the final ending of the Napoleonic Wars in 1815, France and Britain were overtly at war more than $50 \%$ of the time; during this entire period the two were engaged in a bitter commercial and military rivarly (Clodfelter, 1992). While England was bent on using her navy to protect her commercial interests, France wished to severely limit England's "naval-industrial complex" (O'Brien, 2002). Thus for our 18th century study of English trade, we view the English navy as the main protagonistic fleet and the French navy as the main antagonistic fleet, amending (2) to

$$
\text { Trade }_{\text {eng. } . j}=C\left(\frac{Y_{\text {eng }} Y_{j}}{\text { Dist }_{\text {eng. } j}}\right)\left(\frac{e^{\text {EnglishFleet }}}{e^{\text {FrenchFleet }}}\right)
$$

This gravity model needs to be transformed so that it can be empirically verified. We specify the bilateral level of trade between England and another region $j$ as a function of the log of the product of their GDPs, the log of the product of their GDPs per capita, the logged distance between the two regions, the effects of England being at war, and the effects exerted by the global naval powers of the time:

$$
\begin{aligned}
\ln \left(\text { EnglishTrade }_{j t}\right)= & \beta_{0}+\beta_{1} \ln \left(Y_{\text {eng }} Y_{j}\right)_{t}+\beta_{2} \ln \left(Y_{\text {eng }} Y_{j} / \text { Pop eng }_{\text {eno }}\right)_{t}+\beta_{3} \ln \left(\text { Dist }_{j}\right)+\beta_{4} \text { Colony }_{j}+\phi_{1} \text { NavalWar }_{t} \\
& +\sum_{k=1}^{N} \phi_{k+1} \text { PwrShips }_{k t}+\alpha_{j}+\varepsilon_{j t}
\end{aligned}
$$



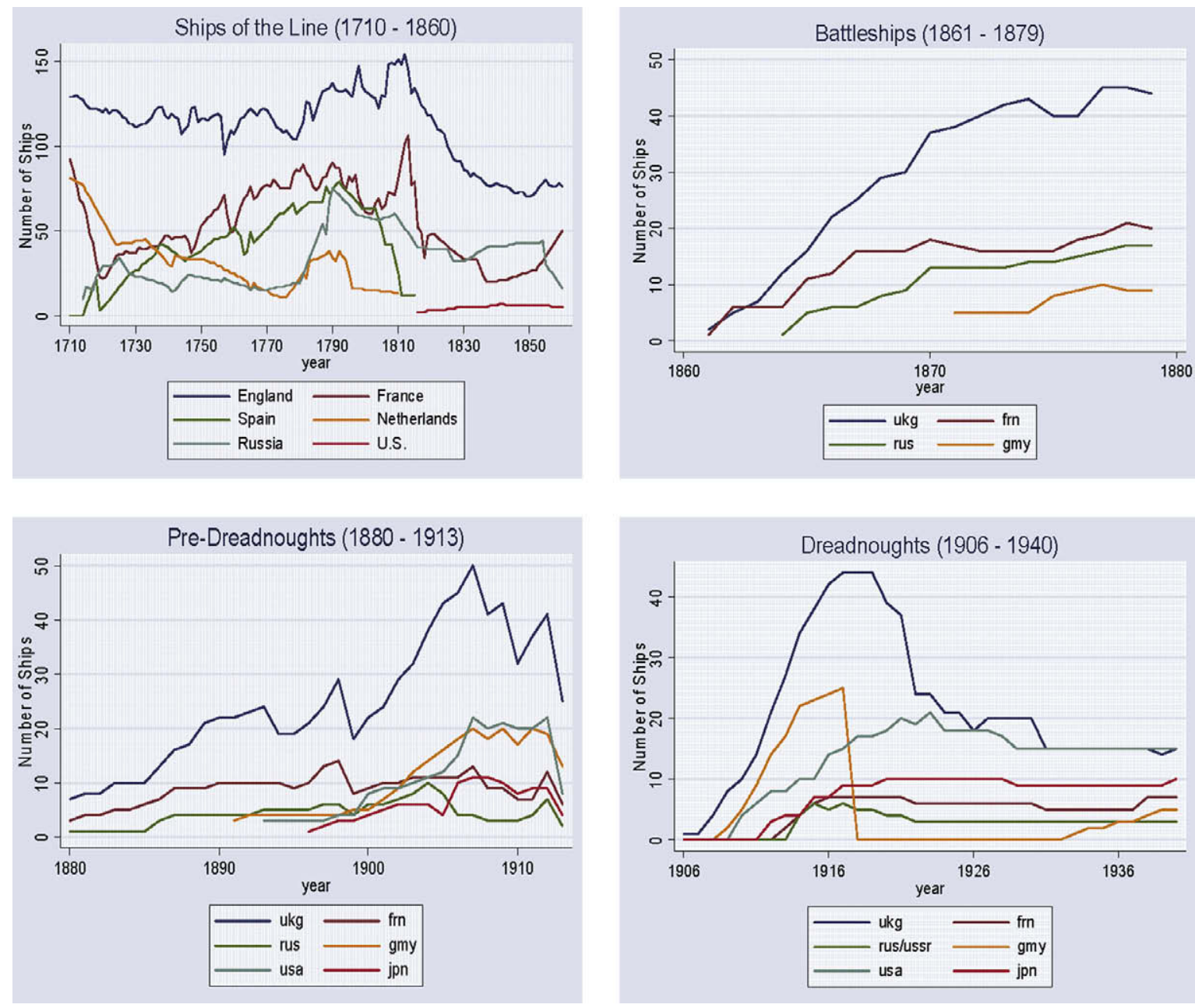

Fig. 4. Ship count data from Modelski and Thompson (1988).

where Dist $_{j}$ is the great circle distance between England and region $j$, Colony $y_{j}$ is an indicator variable which equals 1 if $j$ was/is an English colony (essentially a North America dummy), NavalWar $r_{t}$ is an indicator variable which equals 1 if England is at war with another naval power at time $t$, and PwrShips $s_{k t}$ is the number of ships-of-the-line owned by naval power $k$ at time $t$.

Note that our 18th century power-ship measures only include the intensive measure of antagonistic naval power. Since England and France were consistent rival nations during the 18th century, this is appropriate because hostilities remained throughout this period.

\subsection{Data sources}

For our simple 18th century study of English trade we rely on Deane and Mitchell (1962) for English bilateral trade between seven general regions from 1710 to $1820 .{ }^{8}$ GDP and population statistics for these regions are compiled from Maddison (2001) for the years 1700 and 1820, and are geometrically interpolated to construct annual series. ${ }^{9}$ For ships-of-the-line we use the Modelski and Thompson (1988) source discussed in section 2.3. ${ }^{10}$ We also have trade figures between France and 15 regions for the years 1796-1822 from Chabert (1945). ${ }^{11}$ Descriptive and summary statistics for some of these series are reported in Table 1.

\footnotetext{
8 These regions are Northern Europe, Southern Europe, British North America, the United States, Asia, Africa, and Latin America.

${ }^{9}$ We also use alternative annual GDP figures for England using data compiled by Broadberry and van Leeuwen (2008) as a check. Results (not reported) do not significantly vary.

10 Glete (1993) has similar measures for this time period, as well as measures for smaller vessels, but only in 5-year intervals.

11 These regions are Austria, Denmark, England, German states, Italy, the Netherlands, Portugal and her colonies, Spain and her colonies, Sweden, Switzerland, the United States, Hanseatic Cities, the Ottoman Empire, Prussia, and Russia. For the first eleven regions we were able to match income and population statistics from Maddison (1995).
} 
Table 1

Descriptive and summary statistics, 18th and early 19th century English and French trade

English trade (1710-1822)

French trade (1796-1822)

\section{Total}

Pair-year observations

\section{5}

7

295

15

Variable

$\ln \left(\right.$ EnglishTrade $_{\mathrm{j}}$ )

$\ln \left(Y_{\text {eng }} Y_{j}\right)$

$\ln \left(Y_{\text {eng }} Y_{j} /\right.$ Pop eng $\left._{\text {Pop }}\right)$

Naval War ${ }_{i j}$

British ships-of-the-line

French ships-of-the-line

Spanish ships-of-the-line

Dutch ships-of-the-line

Russian ships-of-the-line

Mean

6.4

33.4

13.8

0.51

122.1

61.5

43.2

32.4

32.9

Standard dev.

1.6

2.2

0.35

0.5

11.0

19.1

21.05

17.3

17.6

$\begin{array}{ll}\text { Min } & \text { Max } \\ 1.9 & 9.0 \\ 27.8 & 37.3 \\ 13.2 & 14.6 \\ 0 & 1 \\ 95 & 154 \\ 22 & 106 \\ 0 & 79 \\ 11 & 81 \\ 10 & 75\end{array}$

\subsection{Estimation results}

We begin by estimating (4) using the English trade data from 1710 to 1822 with seven trade partners. In this earlier study, potentially antagonistic naval powers (size of the French fleet, Spanish fleet, etc.) evolve only in the time dimension; as such year dummies are not included. Luckily there is a lot of time variation in the number of ships-of-the-line maintained by each navy during this period (see Fig. 3).

Table 2 presents some of our findings. Specifications 3 and 4 include all five navies with global power during this time; French naval power is consistently associated with lower English trade, while British naval power is associated with higher English trade. What is perhaps surprising is that despite France's reliance on guerre de course and small-ship guerrilla raids on English commerce, their large naval vessels appear to have inflicted some damage as well. Specification 6 is our most preferred specification, which looks at only English and French naval power and includes pair-fixed effects. Here it would appear that English and French power vessels were fairly equally matched - one extra French ship-of-the-line is associated with a $0.8 \%$ decline of British trade, while one extra English ship-of-the-line is associated with a $0.8 \%$ increase in British trade. A one standard-deviation increase in French power vessels is roughly 19 ships; this would translate into more than a $14 \%$ decline in British trade. On the other hand, a one standard-deviation increase in British power vessels is roughly 11 ships; this would translate into over a 9\% increase in British trade. While the English figures are likely to be upward biased (greater trade will induce the English to build a stronger navy to defend it), the French figures seem to imply that their large vessels did in fact contribute to the disruption of English commerce.

For the years between 1793 and 1815, with only a small pause with the Peace of Amiens from the spring of 1802 until the spring of 1803, the major fight for dominance in Europe was between France and England (Davis and Engerman, 2006). Further, each country used their navies as tools for mercantilistic policies to restrict the trade of neutral nations with their rival. Thus we have a natural experiment that allows us to gauge the effect of each country's navy on the other country's trade volume. ${ }^{12}$ As England and France were antagonistic towards each other throughout this time period, we once again do not distinguish between the extensive and intensive margins of conflict; thus we estimate a version of Eq. (4). Results are reported in Table 3. The fixed effects model is as parsimonious as possible, as fleet sizes are the only independent variables that vary over time, and these models fail to explain most of the actual variations in bilateral trade. Still, it is interesting to observe that each naval power appears to have been able to limit the other nation's trade - for each extra ship-of-the-line, roughly $2 \%$ of the enemy's trade is lost. All considered, the ships-of-the-line used in Continental System of France and the British blockade did have an impact on the magnitude of international commerce, as well as on the geographic pattern of trade.

Pitting England and France against each other in this fashion creates an intriguing study for economists and historians, but also creates a number of issues that renders this a somewhat "naive" approach. Because England and France serve as both trading countries and naval powers, we can not convincingly rule out the possibility of reverse feedback (at least for our protagonistic measures) - ideally we would like the naval power to be a third party influencing two other trading regions. Further, their close proximity to each other gives greater prominence to smaller vessels, and to guerre de course strategies in general. In fact during this period it was the smaller vessels (chiefly 5th and 6th rates, and even unrated vessels) that carried out the bulk of war against enemy trade (Hill, 1999; Wareham, 2001). And privateers were a much more significant impediment to trade in the 18th century than later on, further vitiating the significance of larger war vessels. ${ }^{13}$ Not surprisingly then, the explanatory power of large vessels is quite limited for this time period.

\footnotetext{
12 Alternatively O’Rourke (2006) looks at deteriorating terms of trade for European countries to highlight the deleterious trade effects of this conflict.

13 Historically, limited naval capability compelled nations to authorize private warships, or "privateers," to engage in commerce-raiding activities at sea (by issuing letters of marque). However, as navies grew stronger and more specialized and merchant ships distinguished themselves from warships, the power of privateers began to erode in the early 19th century. Still, privateering was considered to be enough of a nuisance for countries to agree to outlaw it by the Declaration of Paris in 1856. We should further note that the United States, with its small navy, did not ratify the Declaration, partly because it wished to reserve the option of using privateers for the future (Gerace, 2004). After this point commerce-raiding was predominantly a function of professional navies.
} 
Table 2

A naive approach - pooled panel gravity models of English trade, 1710-1822.

\begin{tabular}{|c|c|c|c|c|c|c|}
\hline & 1 & 2 & 3 & 4 & 5 & 6 \\
\hline War & $\begin{array}{l}-0.18 \\
(0.12)\end{array}$ & $\begin{array}{l}-014^{* * *} \\
(0.05)\end{array}$ & $\begin{array}{l}-0.13 \\
(0.14)\end{array}$ & $\begin{array}{l}-0.06 \\
(0.05)\end{array}$ & $\begin{array}{c}-0.11 \\
(0.12)\end{array}$ & $\begin{array}{l}-0.12^{* *} \\
(0.053)\end{array}$ \\
\hline French Pwr Fleet & & & $\begin{array}{l}-0.013^{* * *} \\
(0.004)\end{array}$ & $\begin{array}{l}-0.007^{* *} \\
(0.0028)\end{array}$ & $\begin{array}{c}-0.01 \\
(0.007)\end{array}$ & $\begin{array}{l}-0.008^{* * *} \\
(0.001)\end{array}$ \\
\hline British Pwr Fleet & - & - & $\begin{array}{l}0.01^{*} \\
(0.006)\end{array}$ & $\begin{array}{l}0.013^{* * *} \\
(0.004)\end{array}$ & $\begin{array}{l}0.005 \\
(0.009)\end{array}$ & $\begin{array}{l}0.008^{* * *} \\
(0.002)\end{array}$ \\
\hline Spanish Pwr Fleet & - & - & $\begin{array}{l}0.003 \\
(0.003)\end{array}$ & $\begin{array}{l}0.005 \\
(0.003)\end{array}$ & - & - \\
\hline Dutch Pwr Fleet & - & - & $\begin{array}{l}0.003 \\
(0.003)\end{array}$ & $\begin{array}{l}-0.009^{* * *} \\
(0.003)\end{array}$ & - & - \\
\hline Russian Pwr Fleet & - & - & $\begin{array}{l}-0.004^{*} \\
(0.0022)\end{array}$ & $\begin{array}{l}0.004 \\
(0.003)\end{array}$ & - & - \\
\hline In Product GDPs & $\begin{array}{l}0.52^{* * *} \\
(0.05)\end{array}$ & $\begin{array}{l}-0.1 \\
(0.26)\end{array}$ & $\begin{array}{l}0.62^{* * *} \\
(0.02)\end{array}$ & $\begin{array}{l}-0.83^{* *} \\
(0.4)\end{array}$ & $\begin{array}{l}0.54^{* * *} \\
(0.038)\end{array}$ & $\begin{array}{l}0.02 \\
(0.26)\end{array}$ \\
\hline In Product GDP/pop & $\begin{array}{l}181^{* * *} \\
(0.49)\end{array}$ & $\begin{array}{l}337^{* * *} \\
(0.96)\end{array}$ & $\begin{array}{l}1.86^{* * *} \\
(0.26)\end{array}$ & $\begin{array}{l}4.65^{* * *} \\
(1.25)\end{array}$ & $\begin{array}{l}1.94^{* * *} \\
(0.42)\end{array}$ & $\begin{array}{l}3.06^{* * *} \\
(0.96)\end{array}$ \\
\hline In Distance & $\begin{array}{l}-0.59^{* * *} \\
(0.14)\end{array}$ & - & $\begin{array}{l}-0.65^{* * *} \\
(0.085)\end{array}$ & - & $\begin{array}{l}-0.56^{* * *} \\
(0.12)\end{array}$ & - \\
\hline Colony & $\begin{array}{l}1.48^{* * *} \\
(0.20)\end{array}$ & - & $\begin{array}{l}2.03^{* * *} \\
(0.15)\end{array}$ & - & $\begin{array}{l}1.5^{* * *} \\
(0.16)\end{array}$ & - \\
\hline$R$-squared & 0.77 & 0.39 & 0.82 & 0.01 & 0.78 & 0.57 \\
\hline Number of Obs. & 775 & 775 & 656 & 656 & 775 & 775 \\
\hline Number of country pairs & 7 & 7 & 7 & 7 & 7 & 7 \\
\hline Pair fixed effects & No & Yes & No & Yes & No & Yes \\
\hline
\end{tabular}

Dependent variable is logged bilateral trade. Constant not reported.

Standard errors in parentheses. Significance at $1 \%, 5 \%$, and $10 \%$ indicated by ${ }^{* * *},{ }^{* *}$, and ${ }^{*}$, respectively.

Table 3

Trade effects of French navy versus English navy, 1796-1822.

\begin{tabular}{|c|c|c|c|c|}
\hline & English trade & English trade & French trade & French trade \\
\hline French Pwr Fleet & $\begin{array}{l}-0.02^{* * *} \\
(0.006)\end{array}$ & $\begin{array}{l}-0.02 \\
(0.005)\end{array}$ & $\begin{array}{r}-0.002 \\
(0.006)\end{array}$ & $\begin{array}{r}-0.002 \\
(0.006)\end{array}$ \\
\hline British Pwr Fleet & $\begin{array}{l}0.01 \\
(0.01)\end{array}$ & $\begin{array}{l}0.01^{*} \\
(0.007)\end{array}$ & $\begin{array}{l}0.0000 \\
(0.01)\end{array}$ & $\begin{array}{l}-0.02^{* * *} \\
(0.008)\end{array}$ \\
\hline In Product GDPs & $\begin{array}{l}0.37^{* * *} \\
(0.04)\end{array}$ & - & $\begin{array}{l}0.77^{* * *} \\
(0.26)\end{array}$ & - \\
\hline In Product GDP/pop & $\begin{array}{l}2.15^{* * *} \\
(0.44)\end{array}$ & - & $\begin{array}{l}0.8 \\
(1.3)\end{array}$ & - \\
\hline In Distance & $\begin{array}{l}0.000 \\
(0.005)\end{array}$ & - & $\begin{array}{l}-0.00003 \\
(0.00008)\end{array}$ & - \\
\hline$R$-squared & 0.62 & 0.03 & 0.24 & 0.02 \\
\hline Number of Obs. & 168 & 168 & 211 & 295 \\
\hline Number of country pairs & 7 & 7 & 11 & 15 \\
\hline Pair fixed effects & No & Yes & No & Yes \\
\hline
\end{tabular}

Dependent variable is logged bilateral trade. Year dummies and constant not reported.

Standard errors in parentheses. Significance at $1 \%, 5 \%$, and $10 \%$ indicated by ${ }^{* *},{ }^{* *}$, and *, respectively.

\section{The 19th and 20th centuries}

The difficulties in the 18th century context motivate us to develop a different approach. The world we would like to investigate is one where inter-continental trade is relatively large, where large naval vessels have significant global reach, and where there are many trading partners. In this world, we can view large naval powers as third parties that exert externalities upon the trading world - thus country $i$ may have lower trade with country $j$ because it is fighting with naval power $k$, while $i$ may have higher trade with $j$ because it has an alliance with naval power $l$. Only in a world of many bilateral trading partners can we thus exploit such triangular relationships to determine the causal effects of such conflicts and alliances. Due in part to England's naval successes during the long 18th century, the world of the 19th and early 20th centuries was indeed a globalized one. It is this world to which we next turn.

\subsection{Measures of naval power}

We would like to empirically test Eq. (2) for 19-20th century trade for a wide range of trading partners. But what measures should we use for ProtagFleet ${ }_{i j}$ and AntagFleet $_{i j}$ ? The answer to this is somewhat easier for the 18th century case of Eng- 
lish trade; the two primary naval powers of the time, England and France, were constantly at war with each other and maintained very comparable ships-of-the-line in their fleets. But for the broader 19-20th century study, where there are many trading country-pairs, things are more complicated. Two primary issues come to mind.

\subsubsection{Changes in relevant ships}

The question of what constitutes a "power ship," that is, a naval vessel that has enough global reach to affect something like international commerce in far-off waters, has nettled navalists for some time. As discussed in section 2.3, technological progress in shipping and warfare had rendered useless (at least from a global power perspective) wooden sailing warships in the 1860s, iron-hulled warships in the 1880s, pre-Dreadnought battleships in the 1910s, and Dreadnought battleships in the 1940s. Thus producing long time-series of comparable naval capabilities for naval powers is challenging.

\subsubsection{Changes in conflict}

As international alliances and conflicts between naval powers and other nations flare up and die out, the size/scope of each country's "protagonistic navy" and "antagonistic navy" fluctuates over time. Fig. 5 provides us some sense of the variation of conflicts between nations over time, where at least one of the warring countries is a naval power. For example, whether or not the United States Navy is a detriment to trade between Mexico and Venezuela will depend on whether or not the US navy should be considered part of the antagonistic fleet of this particular trading pair. From the figure, we see that it should be considered part of the antagonistic fleet in the early 1840s (due to fighting between the US and Mexico) and in the early 1900s (due to fighting between the US and Venezuela).

Thus we have two interacting measures of "naval power" that evolve over time. To exploit these variations, we construct the following measure of antagonistic naval power for each country-pair:
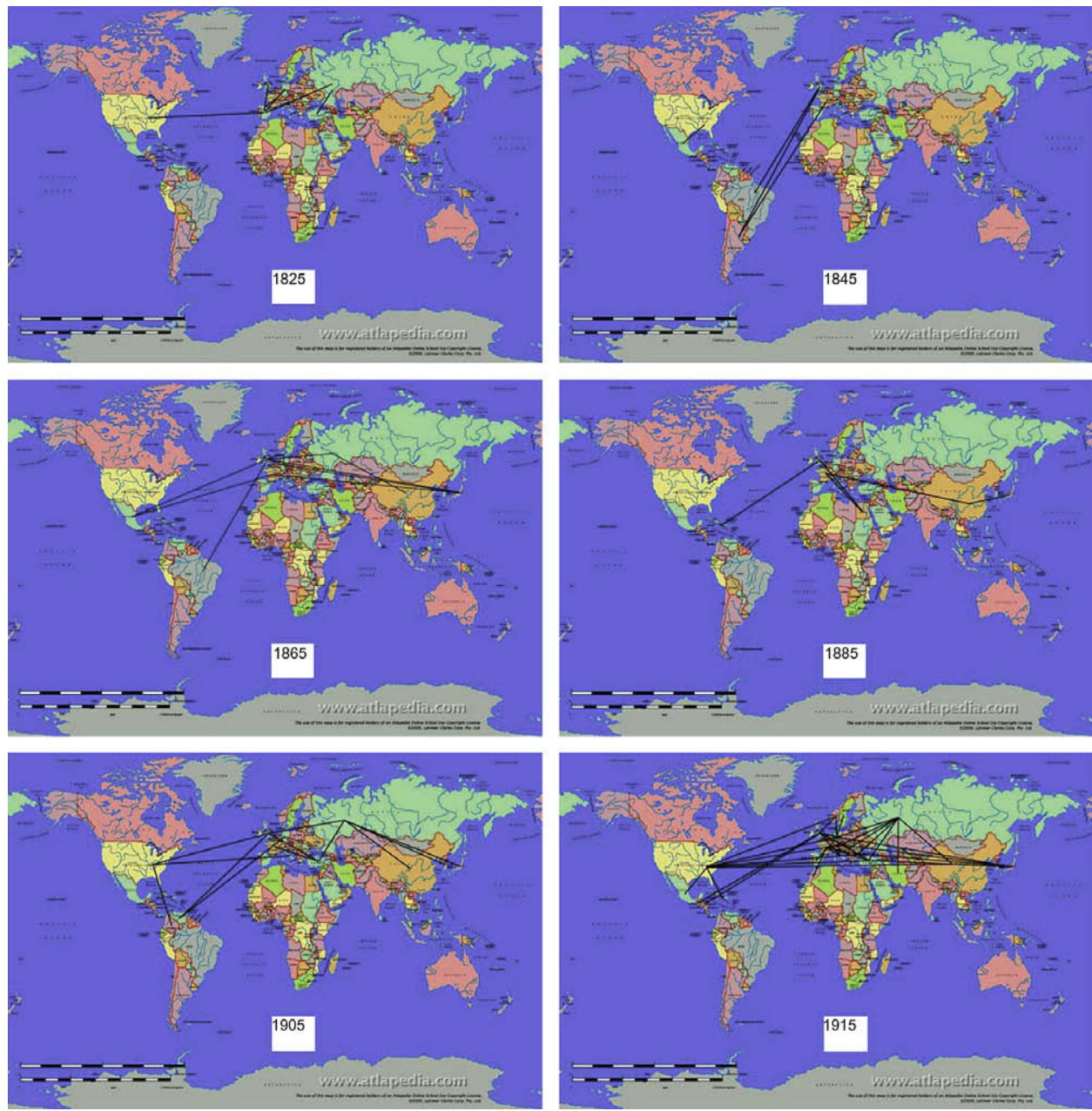

Fig. 5. Conflicts involving naval powers. Each line marks aconflict involving one or two naval "super-powers". 


$$
\text { AntagFleet }_{i j}=\sum_{k=1}^{N}\left(\text { War }_{i k} \text { PowerShips }_{k}+\text { War }_{j k} \text { PowerShips }_{k}\right), \quad k \neq i, k \neq j
$$

where War is a dummy variable indicating whether or not one of the trading partners $(i$ or $j)$ is currently in conflict with a naval power $(k)$, PowerShips is the number of global power war ships currently available to $k$, and $N$ is the number of global naval powers. The first term on the right-hand-side is the antagonistic fleet measure applicable for country $i$, while the second term is the antagonistic fleet measure for country $j .{ }^{14}$ Note that any antagonistic naval power that happens to be one of the trading partners is excluded; this is to ensure that the naval powers are truly third parties so that we are capturing spillover effects.

An analogous measure is used for ProtagFleet. Instead of using a war dummy, however, we use the dummy variable Ally to indicate whether or not one of the trading partners currently has a formal alliance with a naval power (again making sure that these powers are not one of the trading pairs).

$$
\text { ProtagFleet }_{i j}=\sum_{k=1}^{N}\left(\text { Ally }_{i k} \text { PowerShips }_{k}+\text { Ally }_{j k} \text { PowerShips }_{k}\right), \quad k \neq i, k \neq j
$$

Note that the measure PowerShips are ships considered to have global reach at the time. Due to obsolescence, then, we must divide our sample into four distinct time periods - before 1860, PowerShips are ships-of-the-line; from 1861 to 1879 they are battleships; from 1880 to 1913 they are pre-Dreadnoughts; from 1906 to 1940 they are Dreadnoughts.

We would also like to construct longer series of comparable naval statistics so that we might run longer panels. Of course our efforts here are frustrated by the adoption and obsolescence of different naval vessels throughout our 120 years of study. However, we can use naval expenditure data, which is available for the UK, France, and the United States back to 1816, and for all six naval powers back to 1875 . These expenditures can then be used to construct "capital stocks" of naval capacity. Of course this procedure implicitly assumes that $1 £$ spent on the Royal navy during some year translates into the same increase in global power as $1 £$ spent on the US navy during the same year. Naturally, there may be some heterogeneities among countries in technological sophistication and in the share of overall expenditures going to "global power vessels" (for example, the early US navy operated more like the Coast Guard, appropriating much of its funds towards shoreline activities and less towards vessels with global reach) (McBride, 2000). However, as mentioned in section 2.3, differences among the naval leaders were fairly minor; this procedure thus produces a fair measure of naval power, comparable across all the powers.

With this in mind, we construct naval capital stocks as:

$$
\text { NavalCapital }_{k T}=\sum_{t=1}^{10} \delta^{t} I_{k, T-t}
$$

where $I_{k T}$ is investment in naval capital by naval power $k$ at time $T$, and $\delta$ is the annual depreciation rate of NavalCapital. We arbitrarily set $\delta=0.9 .^{15}$ Also arbitrary is how far back we use investment data to construct the stock of capital, which here is 10 years. Analogous to (5), we interact war dummies with this naval capital measure to produce an antagonistic naval measure relevant for countries $i$ and $j$ :

$$
\text { AntagCapital }_{i j}=\sum_{k=1}^{N}\left(\text { War }_{i k} \text { NavalCapital }_{k}+\text { War }_{j k} \text { NavalCapital }_{k}\right), \quad k \neq i, k \neq j
$$

And analogously for our protagonistic measure we have

$$
\text { ProtagCapital }_{i j}=\sum_{k=1}^{N}\left(\text { Ally }_{i k} \text { NavalCapital }_{k}+\text { Ally }_{j k} \text { NavalCapital }_{k}\right), \quad k \neq i, k \neq j
$$

Replacing AntagFleet with AntagCapital and ProtagFleet with ProtagCapital in our specifications allows us to experiment with an alternative measure of naval power, one that is comparable both across countries and across the 19th and 20th centuries, thus allowing us to use a longer panel.

\subsection{Empirical strategy}

In order to judge the validity of our idea we need to transform Eq. (2) so that we can empirically test it.

For our broader study of the period 1820-1940, with many bilateral trade partners, third-party naval powers can be considered friend, foe or neutral. Thus distinguishing between the extensive and intensive effects of naval conflict makes sense in this context. For this case, we specify the bilateral level of trade between any two countries $i$ and $j$ as a function of the log

\footnotetext{
${ }^{14}$ Here we should note that we can also control for potential distance effects by constructing an alternate measure of antagonistic fleet per unit distance: AntagFleet ${ }_{i j}=\sum_{k=1}^{N}\left(\frac{\text { War }_{i k} \text { PowerShips }_{k}+\text { War }_{j k} \text { PowerShips }_{k}}{\text { AvgDist }_{i j k}}\right)$ where AvgDist is an arithmetic average of the great circle distances between $i$ and $k$ and between $j$ and $k$. The overall conclusions do not change, so these results are not reported.

15 Note that this depreciation rate does not change over time; therefore it can not adjust when ships are lost at sea due to warfare, or when different rates of technological obsolescence occur during different periods. Such adjustments would be onerous to calculate and would require some ad hoc assumptions.
} 
of the product of their GDPs, the log of the product of their GDPs per capita, other control variables not evolving over time, the effect of their being at war with each other, and the effects of their being either at war or in alliance with naval powers:

$$
\begin{aligned}
\ln \left(\text { Trade }_{i j t}\right)= & \beta_{0}+\beta_{1} \ln \left(Y_{i} Y_{j}\right)_{t}+\beta_{2} \ln \left(Y_{i} Y_{j} / \text { Pop }_{i} \text { Pop }_{j}\right)_{t}+\beta_{3} \ln \left(\text { Dist }_{i j}\right)+\beta_{3} \text { War }_{i j t}+\beta_{4} \ln \left(\text { Area }_{i} \text { Area }_{j}\right)+\beta_{5} \text { Lang }_{i j} \\
& +\phi_{1} \text { NavalWar }_{i j t}+\phi_{2} \text { AntagFleet }_{i j t}+\phi_{3} \text { ProtagFleet }_{i j t}+\alpha_{i j}+\delta_{t}+\varepsilon_{i j t}
\end{aligned}
$$

where $\operatorname{Lang}_{i j}$ is an indicator variable which equals 1 if $i$ and $j$ share the same primary language, War $r_{i j t}$ is an indicator variable which equals 1 if $i$ and $j$ are in conflict with each other, and NavalWar $r_{i j t}$ is an indicator variable which equals 1 if either $i$ or $j$ is in conflict with some naval power $k$ at time $t .{ }^{16}$ Note that here we are separating the possible deleterious effects of fighting a global power between the extensive margin of conflict (the effect of fighting a nation with global reach, captured by $\phi_{1}$ ) and the intensive margin of conflict (the effect of the extent of that global power's reach, captured by $\phi_{2}$ ). While our primary interest is in the intensive margin, separating these two effects is important; we should make sure that trade falls not only because there is a fight with a global power, but also because that country's power fleet can exert an influence on commerce. $^{17}$

Notice that we include a country-pair fixed effects term $\alpha_{i j}$ in each specification. When running our fixed effects model, the trade effects of those variables that do not evolve over time can not be estimated. Indeed, many of the variables traditionally used in the gravity model literature, such as distances, land areas and common languages, will be implicitly absorbed in the $\alpha$ term. Also notice that time dummies are included in the specification.

As our focus is on the estimation of $\phi_{2}$ and $\phi_{3}$, an important question is whether or not our measure AntagFleet and ProtagFleet can be treated as exogenous variables. We feel that they can for a number of reasons. As a third party, the naval power is not a trading partner, only a warring or friendly one. And any influence of trade between $i$ and $j$ on $k$ 's decision to go to war, such as unobserved traits, will be absorbed by $\phi_{1}$, not $\phi_{2}$. To cope with potential feedback, however, we may throw out of our sample those cases where a naval conflict has lasted over a year. The reason for this is that it takes time to build a ship - if the enemy's trade is a source of consideration for naval build-up, it will likely take at least a year from the time of deciding on new naval construction to the time of deploying the new vessel. As it happens, most conflicts do not last as long as that - out of all the conflicts relevant for our study, only around 15\% last one year or longer. That is, conflicts tend to flare up and die out with great frequency. Thus for most of our sample, there would be no opportunity to change expenditures in response to the enemy's trade; the existing fleet would have to be used instead. When discarding those cases of longer conflict (where observations are dropped if $i$ or $j$ 's conflict with a naval power lasts longer than a year), all our results firmly hold.

Finally, we wish to estimate the effects of an antagonistic country spending resources building its naval fleet on bilateral trade. Thus we estimate:

$$
\begin{aligned}
\ln \left(\text { Trade }_{i j t}\right)= & \beta_{0}+\beta_{1} \ln \left(Y_{i} Y_{j}\right)_{t}+\beta_{2} \ln \left(Y_{i} Y_{j} / \text { Pop }_{i} \text { Pop }_{j}\right)_{t}+\beta_{3} \ln \left(\text { Dist }_{i j}\right)+\beta_{3} \text { War }_{i j t}+\beta_{4} \ln \left(\text { Area }_{i} \text { Area }_{j}\right)+\beta_{5} \text { Lang }_{i j} \\
& +\phi_{1} \text { NavalWar }_{i j t}+\phi_{2} \text { AntagCapital }_{i j t}+\phi_{3} \text { ProtagCapital }_{i j t}+\alpha_{i j}+\delta_{t}+\varepsilon_{i j t}
\end{aligned}
$$

where AntagCapital and ProtagCapital are constructed according to Eqs. (8) and (9). ${ }^{18}$ Note that here we specify year dummies as well - while naval expenditures only evolve over the time dimension, the War dummies for $i$ and $j$ evolve both over time and over country pairs. Thus, similar to (10), we can specify the whole range of country-pair fixed effects and time effects. ${ }^{19}$

\subsection{Data sources}

The final dataset used for the 19th and 20th century study is a match-merge of data that can be split into four categories of interest - trade figures, traditional gravity model data, conflict data, and naval power data. Descriptive and summary statistics for these series are provided in Table 4.

The bilateral trade data were assembled from two main sources: Barbieri (1996) and Mitchell (1992, 1993, 1998). The Barbieri (1996) dataset contains bilateral trade data in current US dollars for some 60 countries during the period 18701947. Here data typically measure bilateral trade between countries $i$ and $j$ by summing imports into $i$ from $j$ and into $j$ from $i$. We adjust these figures for inflation by the US CPI Index. We use trade data from Mitchell $(1992,1993,1998)$ for the 18251870 period, as well as to fill in some major gaps in Barbieri's data coverage for 1870-1947. These data are typically reported in local currency units. We converted them into current US dollar terms using the official exchange rate series provided by Global Financial Data and then adjusted for inflation by the US CPI.

\footnotetext{
16 One might question the validity of the above specification if there were a significant number of observations where no trade at all existed between countries $i$ and $j$. However, between 1820 and 1940, our sample includes less than 20 observations where bilateral trade is marked zero, so that a TOBIT specification would be inappropriate.

17 A number of other explanatory variables were included (not reported). One was the cross-term War $_{i j t} *$ ProtagFleet $_{i j t}$ to see if alliances mattered more during times of war. Also included were lagged values of $W_{i j t}$ and NavalWar ${ }_{i j t}$. Including these terms did not alter any of the coefficients, nor did they show as statistically significant themselves.

18 We also use the alternative, more lagged measure NavalCapital ${ }_{k T}=\sum_{t=2}^{10} \delta^{t} I_{k, T-t}$ in constructing antagonistic capital stocks. This is to further limit any possibility of reverse causation. Results do not vary.

${ }^{19}$ Note that we do not log any of our naval measures because many observations are zero. Thus $\phi_{2}$ and $\phi_{3}$ will always be interpreted as semi-elasticity measures.
} 
Table 4

Descriptive and summary statistics, 19 th and 20th centuries trade.

\begin{tabular}{|c|c|c|c|c|c|}
\hline & $1820-1940$ & $1825-1860$ & $1861-1879$ & $1880-1913$ & $1906-1940$ \\
\hline \multicolumn{6}{|l|}{ Total } \\
\hline Pair-year observations & 19,925 & 1124 & 1792 & 6718 & 12,291 \\
\hline \# of country pairs & 621 & 51 & 153 & 307 & 617 \\
\hline Pair-year observations with 'naval war' = 1 & 4825 & 311 & 233 & 1243 & 3187 \\
\hline Pair-year observations with “war’ = 1 & 378 & 40 & 25 & 101 & 237 \\
\hline Variable & Mean & \multicolumn{2}{|c|}{ Standard dev. } & Min & Max \\
\hline $\ln \left(\right.$ bilateral trade $\left._{i j}\right)$ & 16.64 & \multicolumn{2}{|l|}{2.18} & 6.12 & 23.11 \\
\hline $\ln \left(Y_{i} Y_{j}\right)$ & 21.16 & \multicolumn{2}{|l|}{2.01} & 11.72 & 28.34 \\
\hline $\left.\operatorname{In} Y_{i} Y_{j} / \operatorname{Pop}_{i} \operatorname{Pop}_{j}\right)$ & 2.04 & \multicolumn{2}{|l|}{1.08} & -1.5 & 5.27 \\
\hline $\mathrm{War}_{i j}$ & 0.02 & \multicolumn{2}{|l|}{0.12} & 0 & 1 \\
\hline Naval War ${ }_{i j}$ & 0.19 & \multicolumn{2}{|l|}{0.39} & 0 & 1 \\
\hline Antag ships-of-the-line & 0.37 & \multicolumn{2}{|l|}{6.17} & 0 & 230 \\
\hline Protag ships-of-the-line & 0.48 & \multicolumn{2}{|l|}{5.93} & 0 & 197 \\
\hline Antag battleships & 0.048 & \multicolumn{2}{|l|}{1.17} & 0 & 84 \\
\hline Protag battleships & 0.56 & \multicolumn{2}{|l|}{4.73} & 0 & 109 \\
\hline Antag pre-Dreadnoughts & 0.46 & \multicolumn{2}{|l|}{4.10} & 0 & 124 \\
\hline Protag pre-Dreadnoughts & 0.85 & \multicolumn{2}{|l|}{4.56} & 0 & 70 \\
\hline Antag Dreadnoughts & 1.67 & \multicolumn{2}{|l|}{8.88} & 0 & 168 \\
\hline Protag Dreadnoughts & 2.20 & \multicolumn{2}{|l|}{7.06} & 0 & 134 \\
\hline Antag capital (except Russia) & 40.20 & \multicolumn{2}{|l|}{404.10} & 0 & 15521.86 \\
\hline Protag capital (except Russia) & 53.06 & \multicolumn{2}{|l|}{740.85} & 0 & 17303.00 \\
\hline
\end{tabular}

To this dataset, a number of other standard variables are included to estimate a gravity model; these include real GDP, population, and various country-pair characteristics, such as contiguity, distance, etc. Real GDP and per capita GDP data (in 1990 International Geary-Khamis dollars) after 1870 come predominantly from Maddison (1995, 2001), supplemented where necessary by data from Mitchell $(1992,1993,1998)$. GDP figures before 1870 come predominately from Mitchell (1992, 1993, 1998); these series are dollar converted and inflated to 1990 dollar levels using statistics from Global Financial Data. The CIA's World Factbook is used to provide a number of country-specific variables, including latitude and longitude, land area, physically contiguous neighbors and common languages. Whenever appropriate, we make changes in land area to reflect territorial changes based on two sources, Clemens and Williamson $(2000,2001)$.

Our measures of wars and alliances are constructed from the database on militarized interstate disputes collected by the Correlates of War Project (COW) at the University of Michigan. We use the data set MIDB 3.02, a revised version of the COW dataset MID2.1 compiled by Jones et al. (1996). This data set codes the degree of hostility at the participant level, where the participants are sovereign states. The degrees of hostility range from 1 to 5 ; we code our war variable as conflicts with hostility levels of either 4 or 5 (these include blockades, occupations of territory, seizures, clashes, raids, declarations of war, uses of weaponry, and interstate wars). ${ }^{20}$ For ally data, we use the COW Formal Alliance Data Set compiled by Gibler and Sarkees (forthcoming). These data attempt to identify each formal alliance between at least two states that fall into the classes of defense pact, neutrality or non-aggression treaty, or entente agreement. We have Ally ${ }_{i k t}$ equal to one only in cases where naval power $k$ has an explicit defense pact with nation $i$ at year $t$. While this measure surely excludes some de facto alliances that existed without formal compacts, it will nevertheless capture many of the important de jure allegiances between naval and non-naval nations.

Finally, for measures of 19th and 20th centuries seapower, we use Modelski and Thompson (1988). As mentioned before, they construct a panel of data on the number of global power ships and naval expenditures from a variety of sources.

\subsection{Estimation results}

For our broader study of 19th and 20th centuries trade we estimate Eq. (10). Here we distinguish between the extensive effects of global conflict, captured by $\phi_{1}$, and the intensive effects of global conflict, captured by $\phi_{2}$. Note that we might also wish to separate those country-pairs that share a border from those that do not - conceivably, countries at war with a naval power may wish to substitute from maritime trade to land-based trade, where trade with one's neighbor via land routes could serve to shield the nation's commercial activity from possible damage.

Table 5 presents our most preferred results for the entire sample (this is for the fixed-effects specification; Table 7 presents OLS estimates for the whole sample). Here we split our data into four time groupings in accordance with our four different global power ship measures. Our variable AntagFleet is measured as the number of antagonistic power ships. The coefficient on this measure, $\phi_{2}$, is our intensive measure of conflict and the focus of this study. ProtagFleet is measured in

\footnotetext{
${ }^{20}$ From our previous discussion we know that navies have been used to hinder trade not only in times of outright war but also for less explicit forms of aggression; as such we use a broader definition of "conflict" than used in prior literature. We also limit our observations to those conflicts that last at least one week, so as to avoid episodic instances of aggression that have no long-term influences.
} 
Table 5

Pooled panel gravity estimates with fixed and year effects, 1820-1940.

\begin{tabular}{|c|c|c|c|c|}
\hline & $\begin{array}{l}1820-1860 \\
\text { Ships-of-the-line }\end{array}$ & $\begin{array}{l}\text { 1861-1879 } \\
\text { Battleships }\end{array}$ & $\begin{array}{l}1880-1913 \\
\text { Pre-Dreadnoughts }\end{array}$ & $\begin{array}{l}1906-1940 \\
\text { Dreadnoughts }\end{array}$ \\
\hline Naval War & $\begin{array}{l}0.1^{*} \\
(0.053)\end{array}$ & $\begin{array}{l}-0.11^{* *} \\
(0.05)\end{array}$ & $\begin{array}{l}0.013 \\
(0.029)\end{array}$ & $\begin{array}{l}-0.03 \\
(0.03)\end{array}$ \\
\hline Antag Fleet & $\begin{array}{l}-0.005^{* * *} \\
(0.0007)\end{array}$ & $\begin{array}{l}0.0018 \\
(0.002)\end{array}$ & $\begin{array}{l}-0.0024^{* *} \\
(0.001)\end{array}$ & $\begin{array}{l}-0.01^{* * *} \\
(0.001)\end{array}$ \\
\hline Protag Fleet & $\begin{array}{l}0.0015^{* * *} \\
(0.0006)\end{array}$ & $\begin{array}{l}-0.0006 \\
(0.0013)\end{array}$ & $\begin{array}{l}0.006^{* * *} \\
(0.001)\end{array}$ & $\begin{array}{l}-0.0003 \\
(0.001)\end{array}$ \\
\hline War & $\begin{array}{l}-0.28^{* * *} \\
(0.09)\end{array}$ & $\begin{array}{l}-0.15 \\
(0.1)\end{array}$ & $\begin{array}{l}0.03 \\
(0.067)\end{array}$ & $\begin{array}{l}0.07 \\
(0.07)\end{array}$ \\
\hline In Product GDPs & $\begin{array}{l}0.45^{* * *} \\
(0.11)\end{array}$ & $\begin{array}{l}0.28^{* *} \\
(0.14)\end{array}$ & $\begin{array}{l}0.94^{* * *} \\
(0.08)\end{array}$ & $\begin{array}{l}0.90^{* * *} \\
(0.10)\end{array}$ \\
\hline In Product GDP/pop & $\begin{array}{l}0.93^{* * *} \\
(0.21)\end{array}$ & $\begin{array}{l}-0.12 \\
(0.24)\end{array}$ & $\begin{array}{l}-034^{* * *} \\
(0.12)\end{array}$ & $\begin{array}{l}-0.07 \\
(0.11)\end{array}$ \\
\hline$R$-squared & 0.40 & 0.09 & 0.02 & 0.43 \\
\hline Number of Obs. & 1101 & 1697 & 6011 & 10381 \\
\hline Number of country & 51 & 153 & 307 & 617 \\
\hline
\end{tabular}

Dependent variable is logged bilateral trade. Year dummies and constant not reported.

Standard errors in parentheses. Significance at $1 \%, 5 \%$, and $10 \%$ indicated by ${ }^{* * *},{ }^{* *}$, and *, respectively.

a similar fashion, expect we use alliance dummies. In three of the four cases, our AntagFleet measure comes in as significantly negative. Specifically, one extra antagonistic ship-of-the-line in the 19 th century corresponds to $0.5 \%$ lower trade volume, while one extra antagonistic Dreadnought in the 20th century corresponds to $1 \%$ lower trade volume. A one standard-deviation increase in antagonistic ships-of-the-line is over six ships; this would translate into more than a $3 \%$ decline in bilateral trade. A one standard-deviation increase in antagonistic Dreadnoughts is almost nine ships; this would translate into more than an $8.5 \%$ decline in bilateral trade. In cases where the effect is not quite as strong as this (pre-Dreadnoughts) or insignificant (Battleships), the gravity model fits quite poorly with low $R^{2}$ s. Of course, as we stressed in section 2.3 , accurate measures of seapower are more difficult for these time periods, as the late 19th century was a period of technological transition for the major navies of the world. Ships-of-the-line and Dreadnoughts, on the other hand, were far more reliable measures of naval strength. We also observe that in two of the four cases, protagonistic fleets are associated with higher trade volumes.

Table 6 presents parallel results for those country-pairs that share a border. Not surprisingly, both the helpful effects of friendly fleets and the deleterious effects of enemy fleets seem to dissipate. However, it is interesting to note that the effects of AntagFleet on trade remain significantly negative in the case for Dreadnoughts. This may indicate that maritime trade was an important channel of commerce during the first half of the 20th century even among neighboring countries (indeed, within our sample, all nations, including neighboring countries, have access to the sea). Further, it may be difficult if not impossible to quickly switch trade routes due to increased conflict; because of infrastructural issues, such nimbleness is unlikely. Thus, tangling with countries with Dreadnoughts appears to be harmful for your trade, no matter who your trading partner is.

For longer panels, we estimate Eq. (11) by constructing different measures of NavalCapital using Eq. (7). Table 8 presents some of the results. For these we use 10 lags of expenditure data. The first specification uses expenditures from the three countries that have data for the whole time period of our study - England, France and the US ${ }^{21}$ Specifications 4 and 5 include expenditure data for Russia (4) and for Germany and Japan (5), but for curtailed time periods. For every specification except (4), the intensive effect is estimated to be significantly negative; the extensive effect is estimated to be negative for some specifications as well. Specifically, expenditures are measured in millions of 1913 British pounds. Looking at the last specification, then, a 1 million $£$ increase in country $k$ 's naval expenditures at time $t-1$ is expected to lower the global trade of $k$ 's adversaries by $0.1 \%$ at time $t$, unconditional on what these funds were actually spent on. Considering that a single global power warship may cost many millions of pounds to produce and maintain, the marginal effect of such a ship on international commerce can be considerable. For example, a one standard deviation increase in antagonistic naval capital is over 400 million pounds - given our estimate for the 1883-1938 sub-sample, this translates into a roughly one-third reduction in enemy trade. Thus we see that a warring global power will further reduce trade volumes with further investments in global power, as proxied by these expenditure measures. Also note that our proxies of protagonistic naval expenditures appear to positively affect trade only for the 19th and early 20 th centuries.

\footnotetext{
21 Here we should acknowledge that there may arise some concern that World War I drives much of the results. As is clear from Fig. 3, naval expenditures dramatically spiked during this time, especially for the US and Great Britain. This war involved extensive efforts by both sides to blockade the others' trade. Indeed, after initial optimism on each side faded, the war increasingly became an economic struggle where victory was ultimately determined by the resources available to each group (Broadberry and Harrison, 2005). For this reason we split the sample between the 19th and 20th centuries, and present them as specifications (2) and (3) respectively. (2) highlights that the War does not drive the results.
} 
Table 6

Pooled panel gravity estimates with fixed and year effects, 1820-1940 (countries $i$ and $j$ share a border).

\begin{tabular}{|c|c|c|c|c|}
\hline & $\begin{array}{l}1820-1860 \\
\text { Ships-of-the-line }\end{array}$ & $\begin{array}{l}\text { 1861-1879 } \\
\text { Battleships }\end{array}$ & $\begin{array}{l}1880-1913 \\
\text { Pre-Dreadnoughts }\end{array}$ & $\begin{array}{l}\text { 1906-1940 } \\
\text { Dreadnoughts }\end{array}$ \\
\hline Naval War & $\begin{array}{l}0.14 \\
(0.096)\end{array}$ & $\begin{array}{l}-0.005 \\
(0.07)\end{array}$ & $\begin{array}{l}0.064 \\
(0.064)\end{array}$ & $\begin{array}{l}-0.1 \\
(0.12)\end{array}$ \\
\hline Antag Fleet & $\begin{array}{l}-0.002 \\
(.0013)\end{array}$ & $\begin{array}{l}-0.00001 \\
(0.003)\end{array}$ & $\begin{array}{l}-0.001 \\
(0.002)\end{array}$ & $\begin{array}{l}-0.01^{* * *} \\
(0.002)\end{array}$ \\
\hline Protag Fleet & $\begin{array}{l}0.00004 \\
(0.0008)\end{array}$ & $\begin{array}{l}-0.004 \\
(0.004)\end{array}$ & $\begin{array}{l}-0.001 \\
(0.004)\end{array}$ & $\begin{array}{l}0.004 \\
(0.003)\end{array}$ \\
\hline War & $\begin{array}{l}-0.088 \\
(0.116)\end{array}$ & $\begin{array}{l}-0.10 \\
(0.082)\end{array}$ & $\begin{array}{l}-0.003 \\
(0.082)\end{array}$ & $\begin{array}{l}0.12 \\
(0.14)\end{array}$ \\
\hline In Product GDPs & $\begin{array}{l}1.07 \\
(0.184)\end{array}$ & $\begin{array}{l}0.76^{*} \\
(0.39)\end{array}$ & $\begin{array}{l}1.05^{* * *} \\
(0.12)\end{array}$ & $\begin{array}{l}0.37 \\
(0.26)\end{array}$ \\
\hline In Product GDP/pop & $\begin{array}{l}1.04 \\
(0.55)\end{array}$ & $\begin{array}{l}0.45 \\
(0.51)\end{array}$ & $\begin{array}{l}-0.33 \\
(0.21)\end{array}$ & $\begin{array}{l}-0.17 \\
(0.29)\end{array}$ \\
\hline$R$-squared & 0.66 & 0.62 & 0.24 & 0.10 \\
\hline Number of Obs. & 243 & 237 & 681 & 914 \\
\hline Number of country pairs & 11 & 16 & 28 & 41 \\
\hline
\end{tabular}

Dependent variable is logged bilateral trade. Year dummies and constant not reported.

Standard errors in parentheses. Significance at $1 \%, 5 \%$, and $10 \%$ indicated by ${ }^{* * *},{ }^{* *}$, and*, respectively.

Table 7

OLS estimates (robust, clustered) with year effects, 1820-1940.

\begin{tabular}{|c|c|c|c|c|}
\hline & $\begin{array}{l}1820-1860 \\
\text { Ships-of-the-line }\end{array}$ & $\begin{array}{l}\text { 1861-1879 } \\
\text { Battleships }\end{array}$ & $\begin{array}{l}\text { 1880-1913 } \\
\text { Pre-Dreadnoughts }\end{array}$ & $\begin{array}{l}\text { 1906-1940 } \\
\text { Dreadnoughts }\end{array}$ \\
\hline Naval War & $\begin{array}{l}0.11 \\
(0.24)\end{array}$ & $\begin{array}{l}-0.19 \\
(0.2)\end{array}$ & $\begin{array}{l}0.15 \\
(0.13)\end{array}$ & $\begin{array}{l}-0.39^{* * *} \\
(0.09)\end{array}$ \\
\hline Antag Fleet & $\begin{array}{l}-0.006^{* *} \\
(0.003)\end{array}$ & $\begin{array}{l}0.001 \\
(0.0009)\end{array}$ & $\begin{array}{l}-0.009^{* * *} \\
(0.003)\end{array}$ & $\begin{array}{l}-0.0017^{* * *} \\
(0.003)\end{array}$ \\
\hline Protag Fleet & $\begin{array}{l}0.0009 \\
(0.004)\end{array}$ & $\begin{array}{l}-0.007 \\
(0.007)\end{array}$ & $\begin{array}{l}(0.02) \\
-(0.02)\end{array}$ & $\begin{array}{l}(0.003) \\
(0.0003)\end{array}$ \\
\hline War & $\begin{array}{l}0.64 \\
(0.44)\end{array}$ & $\begin{array}{l}-0.09 \\
(0.31)\end{array}$ & $\begin{array}{l}0.33 \\
(0.2)\end{array}$ & $\begin{array}{l}0.38 \\
(0.25)\end{array}$ \\
\hline In Product GDPs & $\begin{array}{l}0.61^{* * *} \\
(0.13)\end{array}$ & $\begin{array}{l}0.57^{* * *} \\
(0.42)\end{array}$ & $\begin{array}{l}0.6^{* * *} \\
(0.05)\end{array}$ & $\begin{array}{l}0.74^{* * * *} \\
(0.03)\end{array}$ \\
\hline In Product GDP/pop & $\begin{array}{l}0.54 \\
(0.57)\end{array}$ & $\begin{array}{l}0.64^{* * *} \\
(0.23)\end{array}$ & $\begin{array}{l}0.67^{* * *} \\
(0.12)\end{array}$ & $\begin{array}{l}0.62^{* * *} \\
(0.08)\end{array}$ \\
\hline In Distance & $\begin{array}{l}-0.17 \\
(0.30)\end{array}$ & $\begin{array}{l}-0.33^{* *} \\
(0.13)\end{array}$ & $\begin{array}{l}-0.33^{* * *} \\
(0.09)\end{array}$ & $\begin{array}{l}-0.47^{* * *} \\
(0.06)\end{array}$ \\
\hline Language & $\begin{array}{l}1.22 \\
(0.88)\end{array}$ & $\begin{array}{l}1.5^{* * *} \\
(0.42)\end{array}$ & $\begin{array}{l}0.91^{* * *} \\
(0.29)\end{array}$ & $\begin{array}{l}0.45^{* * *} \\
(0.17)\end{array}$ \\
\hline In Product Areas & $\begin{array}{l}-0.17 \\
(0.15)\end{array}$ & $\begin{array}{l}-0.06 \\
(0.09)\end{array}$ & $\begin{array}{l}0.02 \\
(0.06)\end{array}$ & $\begin{array}{l}-0.03 \\
(0.03)\end{array}$ \\
\hline In Product Coastline & $\begin{array}{l}0.15 \\
(0.17)\end{array}$ & $\begin{array}{l}0.05 \\
(0.06)\end{array}$ & $\begin{array}{l}-0.04 \\
(0.04)\end{array}$ & $\begin{array}{l}0.04 \\
(0.03)\end{array}$ \\
\hline$R$-squared & 0.47 & 0.39 & 0.48 & 0.62 \\
\hline Number of Obs. & 858 & 1697 & 6011 & 10381 \\
\hline Number of country pairs & 40 & 153 & 037 & 617 \\
\hline
\end{tabular}

Dependent variable is logged bilateral trade. Year dummies and constant not reported.

Standard errors in parentheses. Significance at $1 \%, 5 \%$, and $10 \%$ indicated by ***, **, and *, respectively.

\subsection{Robustness checks}

The analysis so far has treated measures of antagonistic and protagonistic seapower as exogenous to bilateral trade flows. We justify this assumption on two fundamental grounds - we focus strictly on triangular relationships between two trading partners and third naval parties, and we control for unobserved heterogeneities by including country-pair fixed effects. The former tactic echoes Barro and Tenreyro (2003), who tackle the reverse causality problem when estimating the positive trade effects of using a common currency between two countries by using an anchor-currency country as a third-party variable. The latter tactic has been argued by Baier and Bergstrand (2007) as a superior approach to deal with endogeneity concerns than instrumental-variable techniques. For these reasons we feel fairly confident in our conclusions.

Nonetheless, there still may be some lingering concern that trade between countries could influence, directly or indirectly, other countries to build or lessen their naval capacities. For example, naval expenditures could possibly rise during times of global economic downturns, which would in turn lower global commerce. Or, global powers may feel compelled 
Table 8

Pooled panel gravity estimates with fixed and year effects, 1820-1938 (Naval Capital Stocks).

\begin{tabular}{|c|c|c|c|c|c|}
\hline & $1825-1938$ & 1825-1899 & 1900-1938 & $1825-1913$ & $1883-1938$ \\
\hline War & $\begin{array}{l}0.09 \\
(0.06)\end{array}$ & $\begin{array}{l}0.01 \\
(0.06)\end{array}$ & $\begin{array}{l}0.09 \\
(0.07)\end{array}$ & $\begin{array}{l}-0.06 \\
(0.06)\end{array}$ & $\begin{array}{l}0.2^{* * *} \\
(0.06)\end{array}$ \\
\hline Naval War & $\begin{array}{l}-0.045^{* *} \\
(0.02)\end{array}$ & $\begin{array}{l}-0.13^{* * *} \\
(0.03)\end{array}$ & $\begin{array}{l}-0.036 \\
(0.026)\end{array}$ & $\begin{array}{l}-0.07^{* * *} \\
(0.027)\end{array}$ & $\begin{array}{l}0.03 \\
(0.02)\end{array}$ \\
\hline $\begin{array}{l}\text { Antag Capital } 1 \text { ( } 3 \text { navies) } \\
\text { [No Russia, Germany or Japan] }\end{array}$ & $\begin{array}{l}-0.0008^{* * *} \\
(0.00006)\end{array}$ & $\begin{array}{l}-0.0012^{* * *} \\
(0.0005)\end{array}$ & $\begin{array}{l}-0.0008^{* * *} \\
(0.00007)\end{array}$ & - & - \\
\hline $\begin{array}{l}\text { Protag Capital } 1 \text { ( } 3 \text { navies) } \\
\text { [No Russia, Germany or Japan] }\end{array}$ & $\begin{array}{l}0.00009 \\
0.00006\end{array}$ & $\begin{array}{l}(0.0024)^{* * *} \\
(0.0003)\end{array}$ & $\begin{array}{l}-0.00004 \\
(0.00007)\end{array}$ & - & - \\
\hline $\begin{array}{l}\text { Antag Capital } 2 \text { ( } 4 \text { navies) } \\
\text { [No Germany or Japan] }\end{array}$ & - & - & - & $\begin{array}{l}-0.00005 \\
(0.0002)\end{array}$ & - \\
\hline $\begin{array}{l}\text { Protag Capital } 2 \text { ( } 4 \text { navies) } \\
\text { [No Germany or Japan] }\end{array}$ & - & - & - & $\begin{array}{l}0.0024^{* * *} \\
(0.0002)\end{array}$ & - \\
\hline $\begin{array}{l}\text { Antag Capital } 3 \text { (5 navies) } \\
\text { [No Russia] }\end{array}$ & - & - & - & & $\begin{array}{l}-0.001^{* * *} \\
(0.00007)\end{array}$ \\
\hline $\begin{array}{l}\text { Protag Capital } 3 \text { ( } 5 \text { navies) } \\
\text { [No Russia] }\end{array}$ & - & - & - & & $\begin{array}{l}0.00009 \\
(0.00006)\end{array}$ \\
\hline In Product GDPs & $\begin{array}{l}0.68^{* * *} \\
(0.03)\end{array}$ & $\begin{array}{l}0.30^{* * *} \\
(0.04)\end{array}$ & $\begin{array}{l}0.94^{* * *} \\
(0.08)\end{array}$ & $\begin{array}{l}0.48^{* * *} \\
(0.04)\end{array}$ & $\begin{array}{l}0.78^{* * *} \\
(0.05)\end{array}$ \\
\hline In Product GDP/pop & $\begin{array}{l}0.24^{* * * *} \\
(0.05)\end{array}$ & $\begin{array}{l}0.55^{* * *} \\
(0.09)\end{array}$ & $\begin{array}{c}-0.08 \\
(0.09)\end{array}$ & $\begin{array}{l}0.37^{* * * *} \\
(0.08)\end{array}$ & $\begin{array}{l}0.079 \\
(0.07)\end{array}$ \\
\hline In Product Areas & $\begin{array}{l}-0.25^{* * *} \\
(0.04)\end{array}$ & $\begin{array}{l}-0.23^{* * *} \\
(0.04)\end{array}$ & $\begin{array}{l}-0.02 \\
(0.08)\end{array}$ & $\begin{array}{l}-0.31^{* * *} \\
(0.04)\end{array}$ & $\begin{array}{l}-0.27^{* * *} \\
(0.06)\end{array}$ \\
\hline$R$-squared & 0.38 & 0.17 & 0.46 & 0.22 & 0.43 \\
\hline Number of Obs. & 17,311 & 5918 & 11,393 & 8809 & 14,087 \\
\hline Number of country pairs & 621 & 206 & 617 & 308 & 618 \\
\hline
\end{tabular}

Dependent variable is logged bilateral trade. Year dummies and constant not reported.

Standard errors in parentheses. Significance at $1 \%, 5 \%$, and $10 \%$ indicated by ${ }^{* * *},{ }^{* *}$, and ${ }^{*}$, respectively.

to build their naval strength when their allies trade more with each other, in order to protect their commercial interests. Is it true that bilateral commerce among other countries plays no role in the decision to build a navy, as we have suggested?

To test for this possibility, we regress naval expenditures for our six naval powers on measures of average degrees of openness between protagonistic and antagonistic countries, as well as other explanatory variables. ${ }^{22}$ Specifically, we test the following specification:

$$
\begin{aligned}
I_{k, t}= & \beta_{0}+\beta_{1} \text { War }_{k, t}+\beta_{2} \text { BattleDays }_{k, t}+\beta_{3} Y_{k, t}+\beta_{4}\left(\frac{\operatorname{trade}_{k, t}}{Y_{k, t}}\right)+\beta_{5}\left(\frac{\sum_{u=1}^{U_{t}}\left(\frac{\text { trade }_{u, t}}{Y_{u, t}}\right)}{U_{t}}\right)+\beta_{6}\left(\frac{\sum_{v=1}^{V_{t}}\left(\frac{\text { trade }_{v, t}}{Y_{v, t}}\right)}{V_{t}}\right) \\
& +\beta_{7}\left(\sum_{i \neq k}^{N-1} I_{i, t-1}\right)+\text { variables }_{\text {lagged }}+\alpha_{k}+\delta_{t}+\varepsilon_{k t}
\end{aligned}
$$

where $I_{k, t}$ is naval expenditures by naval power $k$ at year $t$, War $_{k, t}$ is a dummy variable that equals one if $k$ faced a conflict with a country in the sample during year $t$, BattleDays $_{k, t}$ is the number of days of conflict $k$ had with all sampled countries during year $t$, trade $e_{u, t}$ measures total imports and exports of country $u$ in year $t, Y_{u, t}$ measures total output of country $u$ in year $t, U$ is the number of countries in the sample that $k$ is at war with, $V$ is the number of countries in the sample that $k$ has a formal alliance with, and variables lagged $_{1}$ indicates the potential inclusion of lagged observations of these variables. $\beta_{5}$ and $\beta_{6}$ thus capture the effects, if any, of average trade activity on the naval expenditures of a warring or friendly power. ${ }^{23} \beta_{7}$ captures the effects of past naval expenditures of other (potential rival) powers on current naval spending.

Results of this exercise are displayed in Tables 9 and 10. Note that because we use 2 sources for GDP figures (Mitchell, 1992, 1993, 1998, and Maddison, 2001), and because these series cover different countries and appear to be not entirely comparable, we use each set separately and report separate results. ${ }^{24}$ The first two columns in each table show that both contemporaneous war and contemporaneous trade of allies are associated with greater naval expenditure, while contemporaneous trade of hostile countries is associated with less naval expenditure (although these are insignificant). These signs are not surprising - we have suggested the reverse causal direction, that a strong allied naval power will allow you to trade more, while a hostile naval power will induce you to trade less. When we add other explanatory variables, these contemporaneous terms are rendered insignificant; their signs are also reversed. When it comes to the decision to expend resources on naval capacity, it

\footnotetext{
22 See Ritchl and Wolf (2003) and Glick and Taylor (2008) for examples of such reverse causality tests.

23 Substituting for other measures, such as openness data weighted by share of GDP, did not alter results.

24 Aggregate trade figures come from Mitchell $(1992,1993,1998)$ and are converted into current US dollar terms using official exchange rate series provided by Global Financial Data and then reflated by the US CPI. Other data come from sources already listed above.
} 
Table 9

Robustness check - model of naval expenditures for six naval powers using output data from Mitchell (1998).

\begin{tabular}{|c|c|c|c|c|c|c|}
\hline Average openness of enemies $t_{t}$ & $\begin{array}{l}-10.9 \\
(27.2)\end{array}$ & $\begin{array}{l}-15.8 \\
(16.7)\end{array}$ & $\begin{array}{l}-2.9 \\
(32.0)\end{array}$ & $\begin{array}{l}-8.0 \\
(18.1)\end{array}$ & $\begin{array}{l}4.8 \\
(26.0)\end{array}$ & $\begin{array}{l}10.5 \\
(13.7)\end{array}$ \\
\hline Average openness of allies $t_{t}$ & $\begin{array}{l}32.5^{* * *} \\
(5.2)\end{array}$ & $\begin{array}{l}36.8^{* * *} \\
(5.7)\end{array}$ & $\begin{array}{l}18.9 \\
(13.5)\end{array}$ & $\begin{array}{l}22.4 \\
(11.4)\end{array}$ & $\begin{array}{l}-4.1 \\
(10.7)\end{array}$ & $\begin{array}{l}-3.1 \\
(10.1)\end{array}$ \\
\hline $\mathrm{War}_{t}$ & $\begin{array}{l}11.7^{*} \\
(6.4)\end{array}$ & $\begin{array}{l}10.6^{* *} \\
(6.1)\end{array}$ & $\begin{array}{l}6.3 \\
(6.8)\end{array}$ & $\begin{array}{l}6.4 \\
(5.6)\end{array}$ & $\begin{array}{l}0.35 \\
(5.7)\end{array}$ & $\begin{array}{l}-2.7 \\
(4.3)\end{array}$ \\
\hline Average openness of enemies ${ }_{t-1}$ & - & - & $\begin{array}{l}-7.1 \\
(29.9)\end{array}$ & $\begin{array}{c}-9.8 \\
(18.9)\end{array}$ & $\begin{array}{l}-5.3 \\
(23.1)\end{array}$ & $\begin{array}{l}-1.2 \\
(14.4)\end{array}$ \\
\hline Average openness of allies $s_{t-1}$ & - & - & $\begin{array}{l}18.9 \\
(14.5)\end{array}$ & $\begin{array}{l}1.6 \\
(14.6)\end{array}$ & $\begin{array}{l}2.5 \\
(13.0)\end{array}$ & $\begin{array}{l}2.1 \\
(12.9)\end{array}$ \\
\hline War $_{t-1}$ & - & - & $\begin{array}{l}6.6 \\
(6.7)\end{array}$ & $\begin{array}{l}6.3 \\
(6.0)\end{array}$ & $\begin{array}{l}5.0 \\
(5.5)\end{array}$ & $\begin{array}{l}3.3 \\
(4.6)\end{array}$ \\
\hline $\mathrm{GDP}_{t}$ & - & - & - & - & $\begin{array}{l}0.0001^{* * *} \\
(0.00001)\end{array}$ & $\begin{array}{l}0.0001^{* * *} \\
(0.000007)\end{array}$ \\
\hline Openness $_{t}$ & - & - & - & - & $\begin{array}{l}29^{* * *} \\
(7.1)\end{array}$ & $\begin{array}{l}-7.5 \\
(9.5)\end{array}$ \\
\hline Number of battle-days ${ }_{t}$ & - & - & - & - & $\begin{array}{l}0.02 \\
(0.02)\end{array}$ & $\begin{array}{l}0.01^{* * *} \\
(0.004)\end{array}$ \\
\hline Number of battle-days $t-1$ & - & - & - & - & $\begin{array}{l}0.01 \\
(0.01)\end{array}$ & $\begin{array}{l}0.01^{* *} \\
(0.005)\end{array}$ \\
\hline Naval expenditures by others ${ }_{t-1}$ & - & - & - & - & $\begin{array}{l}0.02 \\
(0.05)\end{array}$ & $\begin{array}{l}0.05 \\
(0.04)\end{array}$ \\
\hline Naval expenditures by others $s_{t-2}$ & - & -- & - & - & $\begin{array}{l}0.02 \\
(0.05)\end{array}$ & $\begin{array}{l}0.05 \\
(0.04)\end{array}$ \\
\hline$R$-squared & 0.08 & 0.07 & 0.09 & 0.08 & 0.59 & 0.54 \\
\hline Number of Obs. & 590 & 590 & 590 & 590 & 441 & 439 \\
\hline Naval power fixed effect & No & Yes & No & Yes & No & Yes \\
\hline
\end{tabular}

Dependent variable is naval expenditures in constant (1913) pounds. Country coverage for output data from Mitchell (1998) includes Australia, Austria, Belgium, Brazil, Bulgaria, Denmark, Finland, France, Germany, Greece, Italy, Japan, Korea, Norway, Russia, Spain, Sweden, Switzerland, Taiwan, the UK, and the US.

Standard errors in parentheses. Significance at $1 \%, 5 \%$, and $10 \%$ indicated by ${ }^{* * *},{ }^{* *}$, and *, respectively.

appears that the country's wealth and extent of fighting in the past are the important factors, trumping all else. Of course, one would need to develop a far more sophisticated model to truly determine how things like economic and military competition

Table 10

Robustness check - model of naval expenditures for six naval powers using output data from Maddison (2005).

\begin{tabular}{|c|c|c|c|c|c|c|}
\hline Average openness of enemies $t_{t}$ & $\begin{array}{l}2.1 \\
(25.6)\end{array}$ & $\begin{array}{l}-2.9 \\
(10.0)\end{array}$ & $\begin{array}{l}2.0 \\
(26.6)\end{array}$ & $\begin{array}{c}-0.8 \\
(10.1)\end{array}$ & $\begin{array}{l}9.1 \\
(21.1)\end{array}$ & $\begin{array}{l}13.2 \\
(7.1)\end{array}$ \\
\hline Average openness of allies $t$ & $\begin{array}{l}26.0^{* * *} \\
(6.6)\end{array}$ & $\begin{array}{l}33.1^{* * *} \\
(7.2)\end{array}$ & $\begin{array}{l}6.4 \\
(12.7)\end{array}$ & $\begin{array}{l}10.3 \\
(11.5)\end{array}$ & $\begin{array}{l}-6.2 \\
(8.7)\end{array}$ & $\begin{array}{l}-8.5 \\
(8.2)\end{array}$ \\
\hline $\mathrm{War}_{t}$ & $\begin{array}{l}15.7^{* * *} \\
(6.1)\end{array}$ & $\begin{array}{l}13.7^{* * *} \\
(2.9)\end{array}$ & $\begin{array}{l}11.2 \\
(7.0)\end{array}$ & $\begin{array}{l}5.5 \\
(3.4)\end{array}$ & $\begin{array}{l}2.0 \\
(4.9)\end{array}$ & $\begin{array}{l}-0.07 \\
(2.4)\end{array}$ \\
\hline Average openness of enemies ${ }_{t-1}$ & - & - & $\begin{array}{l}35.0 \\
(35.7)\end{array}$ & $\begin{array}{l}28.6^{* * *} \\
(10.6)\end{array}$ & $\begin{array}{l}37.7 \\
(29.3)\end{array}$ & $\begin{array}{l}40.4^{* * *} \\
(7.4)\end{array}$ \\
\hline Average openness of allies $t-1$ & - & - & $\begin{array}{l}1.9 \\
(15.4)\end{array}$ & $\begin{array}{l}3.9 \\
(14.3)\end{array}$ & $\begin{array}{l}1.0 \\
(11.8)\end{array}$ & $\begin{array}{l}-0.9 \\
(10.3)\end{array}$ \\
\hline War $_{t-1}$ & - & - & $\begin{array}{l}-2.9 \\
(7.9)\end{array}$ & $\begin{array}{l}-2.8 \\
(3.6)\end{array}$ & $\begin{array}{l}-6.3 \\
(6.5)\end{array}$ & $\begin{array}{l}-7.6^{* * *} \\
(2.6)\end{array}$ \\
\hline $\mathrm{GDP}_{t}$ & - & - & - & - & $\begin{array}{l}0.0001^{* * *} \\
(0.00001)\end{array}$ & $\begin{array}{l}0.0001^{* * *} \\
(0.000006)\end{array}$ \\
\hline Openness $_{t}$ & - & - & - & - & $\begin{array}{l}29.7^{* * *} \\
(4.7)\end{array}$ & $\begin{array}{l}-22.0 \\
(9.0)\end{array}$ \\
\hline Number of battle-days $t$ & - & - & - & - & $\begin{array}{l}0.07 \\
(0.06)\end{array}$ & $\begin{array}{l}0.01^{* * *} \\
(0.003)\end{array}$ \\
\hline Number of battle-days $t_{t-1}$ & - & - & - & - & $\begin{array}{l}0.004 \\
(0.007)\end{array}$ & $\begin{array}{l}0.01^{* *} \\
(0.004)\end{array}$ \\
\hline Naval expenditures by others $s_{t-1}$ & - & - & - & - & $\begin{array}{l}0.04 \\
(0.04)\end{array}$ & $\begin{array}{l}0.04 \\
(0.03)\end{array}$ \\
\hline Naval expenditures by others $t_{t-2}$ & - & - & - & - & $\begin{array}{l}0.04 \\
(0.05)\end{array}$ & $\begin{array}{l}0.06^{* *} \\
(0.03)\end{array}$ \\
\hline$R$-squared & 0.11 & 0.10 & 0.17 & 0.18 & 0.61 & 0.53 \\
\hline Number of Obs. & 590 & 590 & 582 & 582 & 554 & 551 \\
\hline Naval power fixed effect & No & Yes & No & Yes & No & Yes \\
\hline
\end{tabular}

Dependent variable is naval expenditures in constant (1913) pounds. Country coverage for output data from Maddison (2005) includes Argentina, Austria, Belgium, Bulgaria, Canada, Costa Rica, Cuba, Denmark, El Salvador, Finland, France, Germany, Greece, Guatemala, India, Indonesia, Ireland, Italy, Japan, Korea, Mexico, the Netherlands, New Zealand, Nicaragua, Norway, Peru, the Philippines, Poland, Portugal, Romania, Russia, Spain, Sri Lanka, Sweden, Switzerland, Taiwan, Turkey, the UK, the US. Uruguay, and Venezuela.

Standard errors in parentheses. Significance at $1 \%, 5 \%$, and $10 \%$ indicated by ${ }^{* *},{ }^{* *}$, and ${ }^{*}$, respectively. 
induces military expenditures (such as error correction models of arms races). The point here is only that the trading activities of friends and foes appears to not influence naval build-up decisions. We are therefore justified in placing measures of antagonistic and protagonistic naval power measures on the right hand side of our main regressions.

The other check we perform is to first-difference our observations and test our augmented gravity model on this differenced data. Baier and Bergstrand (2007) suggests that this is an important check if unobserved heterogeneity in trade flows is correlated over time; in such cases the inefficiency of fixed effects grows with the time length of the sample. We test the differenced versions of (2) and (3), and report results in Tables 11 and 12, respectively. In general these differenced regressions provide mixed support for our main hypothesis. This should not be too surprising; after all, it is not obvious that such short term changes in the naval fleets of allies or enemies should affect short term trade, which is what this model tests. Nonetheless, short term increases in antagonistic Dreadnoughts and antagonistic naval capital still appear to lower trade volumes; short term increases in protagonistic Ships-of-the-line or Dreadnoughts on the other hand still appear to increase trade volumes.

\section{Conclusion}

This paper constitutes a global historical study linking commercial and military activities on the high seas. We discover that when summoned to antagonistic action, large naval vessels can inflict significant damage to international trade. These

Table 11

Robustness check - pooled panel gravity estimates with differenced data, 1820-1940 (Power Ships).

\begin{tabular}{|c|c|c|c|c|}
\hline & $\begin{array}{l}1820-1860 \\
\text { Ships-of-the-Line }\end{array}$ & $\begin{array}{l}\text { 1861-1879 } \\
\text { Battleships }\end{array}$ & $\begin{array}{l}1880-1913 \\
\text { Pre-Dreadnoughts }\end{array}$ & $\begin{array}{l}1906-1940 \\
\text { Dreadnoughts }\end{array}$ \\
\hline d(Naval War) & $\begin{array}{l}0.036 \\
(0.025)\end{array}$ & $\begin{array}{l}-0.1^{* * *} \\
(0.03)\end{array}$ & $\begin{array}{l}-0.0007 \\
(0.02)\end{array}$ & $\begin{array}{l}-0.11^{* * *} \\
(0.03)\end{array}$ \\
\hline d(Antag Fleet) & $\begin{array}{l}0.0005 \\
(0.0005)\end{array}$ & $\begin{array}{l}-0.0004 \\
(0.002)\end{array}$ & $\begin{array}{l}-0.0007 \\
(0.0008)\end{array}$ & $\begin{array}{l}-0.003^{* * *} \\
(0.001)\end{array}$ \\
\hline d(Protag Fleet) & $\begin{array}{l}0.0015^{* * *} \\
(0.0006)\end{array}$ & $\begin{array}{l}0.0008 \\
(0.001)\end{array}$ & $\begin{array}{l}-0.003 \\
(0.002)\end{array}$ & $\begin{array}{l}0.003^{* * *} \\
(0.001)\end{array}$ \\
\hline $\mathrm{d}($ War $)$ & $\begin{array}{l}0.007 \\
(0.05)\end{array}$ & $\begin{array}{l}-0.06 \\
(0.11)\end{array}$ & $\begin{array}{l}-0.03 \\
(0.04)\end{array}$ & $\begin{array}{l}0.002 \\
(0.08)\end{array}$ \\
\hline d(In Product GDPs) & $\begin{array}{l}0.98^{*} \\
(0.57)\end{array}$ & $\begin{array}{l}1.36^{* * *} \\
(0.51)\end{array}$ & $\begin{array}{l}-0.06 \\
(0.46)\end{array}$ & $\begin{array}{l}0.50 \\
(0.36)\end{array}$ \\
\hline d(In Product GDP/pop) & $\begin{array}{l}-0.32 \\
(0.21)\end{array}$ & $\begin{array}{l}-1.16^{* *} \\
(0.54)\end{array}$ & $\begin{array}{l}0.8 \\
(0.5)\end{array}$ & $\begin{array}{l}0.64^{*} \\
(0.35)\end{array}$ \\
\hline$R$-squared & 0.03 & 0.01 & 0.01 & 0.04 \\
\hline Number of Obs. & 811 & 1672 & 6529 & 12,188 \\
\hline Number of country pairs & 50 & 160 & 314 & 617 \\
\hline
\end{tabular}

Dependent variable is differenced logged bilateral trade. Constant not reported.

Standard errors in parentheses. Significance at $1 \%, 5 \%$, and $10 \%$ indicated by ${ }^{* * *},{ }^{* *}$, and ${ }^{*}$, respectively.

Table 12

Robustness check - pooled panel gravity estimates with differenced data, 1820-1938 (Naval Capital Stocks).

\begin{tabular}{|c|c|c|c|c|}
\hline & $1825-1938$ & 1825-1899 & $1900-1938$ & $1883-1938$ \\
\hline dWar & $\begin{array}{l}0.02 \\
(0.06)\end{array}$ & $\begin{array}{l}-0.04 \\
(0.04)\end{array}$ & $\begin{array}{l}0.05 \\
(0.09)\end{array}$ & $\begin{array}{l}0.03 \\
(0.06)\end{array}$ \\
\hline d(Naval War) & $\begin{array}{l}-0.05^{* * *} \\
(0.01)\end{array}$ & $\begin{array}{l}-0.02 \\
(0.02)\end{array}$ & $\begin{array}{l}-0.1^{* * * *} \\
(0.02)\end{array}$ & $\begin{array}{l}-0.04^{* *} \\
(0.02)\end{array}$ \\
\hline d(Antag Capital 1) (3 navies) & $-0.0003^{* * *}$ & 0.00002 & $-0.0004^{* * *}$ & - \\
\hline [No Russia, Germany or Japan] & $(0.00008)$ & $(0.0002)$ & $(0.00009)$ & \\
\hline d(Protag Capital 1) (3 navies) & -0.00008 & -0.00006 & -0.00003 & - \\
\hline [No Russia, Germany or Japan] & $(0.00008)$ & $(0.0009)$ & $(0.00007)$ & \\
\hline $\begin{array}{l}\text { d(Antag Capital 3) (5 navies) } \\
\text { [No Russia] }\end{array}$ & - & - & - & $\begin{array}{l}-0.0004^{* *} \\
(0.00008)\end{array}$ \\
\hline $\begin{array}{l}\text { d(Protag Capital 3) (5 navies) } \\
\text { [No Russia] }\end{array}$ & - & - & - & $\begin{array}{l}-0.00008 \\
(0.00008)\end{array}$ \\
\hline d(In Product GDPs) & $\begin{array}{l}0.22 \\
(0.29)\end{array}$ & $\begin{array}{l}-0.81 \\
(0.61)\end{array}$ & $\begin{array}{l}0.49 \\
(0.35)\end{array}$ & $\begin{array}{l}0.16 \\
(0.29)\end{array}$ \\
\hline d(In Product GDP/pop) & $\begin{array}{l}0.88^{* * *} \\
(0.30)\end{array}$ & $\begin{array}{l}1.37^{* *} \\
(0.67)\end{array}$ & $\begin{array}{l}0.67^{*} \\
(0.36)\end{array}$ & $\begin{array}{l}0.99^{* * * *} \\
(0.31)\end{array}$ \\
\hline$R$-squared & 0.035 & 0.01 & 0.05 & 0.037 \\
\hline Number of Obs. & 18,853 & 6108 & 12,168 & 15,685 \\
\hline Number of country pairs & 621 & 206 & 617 & 618 \\
\hline
\end{tabular}

Dependent variable is differenced logged bilateral trade.

Constant not reported. Standard errors in parentheses. Significance at $1 \%, 5 \%$, and $10 \%$ indicated by ${ }^{* * *},{ }^{* *},{ }^{*}$, respectively. 
vessels can also bolster international commerce for allied countries. Further, we have suggested that our measures are robust to reverse causation issues. These large naval ships, designed for the purposes of a number of ex ante strategic missions, can suddenly be summoned to action to aid an ally or help resolve a dispute. These actions however can produce commerceshifting spillovers that we have attempted to quantify.

So was the maintenance of global power vessels "worth it" from a commerce perspective? These ships were stabilizing forces during times of peace, but the naval Pax Britannica of the late 19th century and Pax Americana of the 20th century were maintained no doubt at high cost - by one measure, nearly 10\% of total English GDP was allocated to the Royal Navy around the turn of the 19th century (O'Brien, 1993). While these naval expenditures produced a variety of commerce-related spillovers, both good and bad, the net effects on trade and globalization in general are difficult to discern. The US's antagonism towards Japan for example (by entering Tokyo Bay in 1853, quite uninvited) may have initially been disruptive, but surely unleashed subsequent trade in the Far East; such dynamic effects can not be uncovered by our empirical strategy.

Instead we have attempted to quantity the immediate effects of friendly and fighting war vessels, and thus hope to contribute to the literature assessing the historic costs of war on international commerce. Our unique measures of antagonistic naval powers give us an alternative approach to highlight the effects of war on trade by using third parties as instruments of conflict. These third parties, large super-powers with global reach, could influence international commerce unilaterally thus they provide us a convenient tool to assess the costs of war, as well as serve as the focus of future studies on commercial and military links.

\section{References}

Baier, Scott L., Bergstrand, Jeffrey H., 2007. Do free trade agreements actually increase members' international trade? Journal of International Economics 71, 72-95.

Barbieri, Katherine, 1996. Economic Interdependence and Militarized Interstate Conflict, 1870-1985, Ph.D. dissertation, SUNY Binghampton.

Barbieri, Katherine, 2002. The Liberal Illusion: Does Trade Promote Peace? University of Michigan Press, Ann Arbor.

Barbieri, Katherine, Levy, Jack, 1999. Sleeping with the enemy: the impact of war on trade. Journal of Peace Research 36, 463-479.

Barro, Robert J., Tenreyro, Silvana, 2003. Economic Effects of Currency Unions. NBER Working Paper No. 9435.

Bergeijk, Peter van, 1994. Economic Diplomacy, Trade, and Commercial Policy: Positive and Negative Sanctions in a New World Order. Edward Elgar, Vermont.

Broadberry, Steve, Harrison, Mark, 2005. The economics of World War I - an overview. in: The Economics of World War I, Cambridge University Press, Cambridge.

Broadberry, Stephen, van Leeuwen, Bas, 2008. British Economic Growth and the Business Cycle, 1700-1850: Annual Estimates, manuscript.

Brodie, Bernard, 1944. A Guide to Naval Strategy. Princeton University Press, Princeton.

Chabert, Albert, 1945. Essai sur le mouvement des prix en France de 1798 à 1820, Paris.

Clemens, Michael A., Williamson, Jeffrey G., 2000. Where Did British Foreign Capital Go?. NBER Working Paper No. 8028.

Clemens, Michael A., Williamson, Jeffrey G., 2001. Why the Tariff-Growth Correlation Changed After 1950. NBER Working Paper No. 8459.

Clodfelter, Michael, 1992. Warfare and Armed Conflicts: A Statistical Reference to Casualty and Other Figures, $1618-1991$ (2 vols.), McFarland \& Company, Philadelphia.

Crowhurst, Patrick (1977), The Defense of British Trade, 1689-1815, Dawson \& Sons, Folkerstone.

Cutler, Thomas J., 2002. The Bluejacket's Manual, Centennial Edition, Naval Institute Press, Annapolis.

Davis, Lance E., Engerman, Stanley L., 2006. Naval Blockades in Peace and War - An Economic History Since 1750. Cambridge University Press, New York.

Deane, Phyllis., Mitchell, Brian R., 1962. Abstract of British Historical Statistics. Cambridge University Press, Cambridge.

Findlay, Ronald., O'Rourke, Kevin H., 2007. Power and Plenty: Trade, War and the World Economy in the Second Millennium. Princeton University Press, Princeton.

Flandreau, Marc, 2000. The Economics and Politics of Monetary Unions: A Reassessment of the Latin Monetary Union, 1867-71. Financial History Review 7 (1), 25-43.

Frankel, Jeffrey A., Stein, Ernesto, Wei, Shang Jin, 1996. Regional Trading Arrangements: Natural or Supernatural? American Economic Review 86 (May), $52-$ 56.

Gathmann, Christina, Hillmann, Hennning, 2007. From Privateering to Navy: How Sea Power Became a Public Good, unpublished manuscript.

Gerace, Michael P., 2004. Military Power, Conflict and Trade. Frank Cass Publishing, Portland.

Glete, Jan, 1993. Navies and Nations: Warships, Navies and State Building in Europe and America, 1500-1860, 2 vols. Almqvist and Wiksell International, Stockholm.

Glick, Reuven, Taylor, Alan M., 2008. Collateral Damage: Trade Disruption and the Economic Impact of War. Review of Economics and Statistics, forthcoming.

Harding, Richard, 1999. Seapower and Naval Warfare from 1650-1830. UCL Press, London.

Hill, Richard., 1999. Prizes of War: Prize Law and the Royal Navy in the Napoleonic Wars 1793-1815. Sutton, London.

Jones, Daniel M., Bremer, Stuart M., Singer, J. David, 1996. Militarized Interstate Disputes, 1816-1992: Rationale, Coding Rules, and Empirical Patterns. Conflict Management and Peace Science 15 (2), 163-210.

Lewis, Michael, 1959. History of the British Navy. Essential Books, Fair Lawn, NJ.

López-Córdova, J. Ernesto, Meissner, Christopher, 2003. Exchange-Rate Regimes and International Trade: Evidence from the Classical Gold Standard Era, 1870-1913. American Economic Review 93 (1), 344-353.

Maddison, Angus, 1995. Monitoring the World Economy, 1820-1992. OECD, Paris.

Maddison, Angus, 2001. The World Economy: A Millennial Perspective. OECD, Paris.

Mahan, Alfred T., 1890. The Influence of Sea Power upon History, 1660-1783. Wang Hill, New York.

Mansfield, Edward D., Bronson, Rachel, 1997. Alliances, Preferential Trading Arrangements, and International Trade. American Political Science Review 91 (1), 94-107.

Mansfield, Edward D., Pevehouse, J.C., 2000. Trade Blocs, Trade Flows, and International Conflict. International Organization 54, 775-808.

McBride, William M., 2000. Technological Change and the United States Navy, 1865-1945. The Johns Hopkins University Press, Baltimore.

Mitchell, Brian R., 1992. International Historical Statistics: Europe, 1750-1988. Stockton Press, New York.

Mitchell, Brian R., 1993. International Historical Statistics: The Americas, 1750-1988. Stockton Press, New York.

Mitchell, Brian R., 1998. International Historical Statistics: Africa, Asia \& Oceania, 1750-1988. Stockton Press, New York.

Mitchener, Kris J., Weidenmier, Marc, 2008. Trade and Empire. Economic Journal 118 (November), 1805-1834.

Modelski, George, Thompson, William R., 1988. Seapower in Global Politics, 1494-1993. The University of Washington Press, Seattle.

Neal, Larry, 1994. War Finance: Volume I: War from Antiquity to Artillery, Edward Elgar Publishing, Cheltenham, UK. 
O’Brien, Patrick K., 1993. Political Preconditions for the Industrial Revolution. In: The Industrial Revolution and British Society, Cambridge University Press, Cambridge.

O’Brien, Patrick K., 2002. Philip's Atlas of World History. Philip's, London.

O’Brien, Phillips Payson (Ed.), 2001. Technology and Naval Combat in the Twentieth Century and Beyond. Frank Cass Publishers, London.

Oneal, John, Russett, Bruce, 1997. The Classical Liberals Were Right: Democracy, Interdependence and Conflict, 1950-1985. International Studies Quarterly 41, 267-294.

O'Rourke, Kevin H., 2006. The Worldwide Economic Impact of the Revolutionary and Napoleonic Wars, 1793-1815. Journal of Global History 1, 123-149. Padfield, Peter, 1972. Guns at Sea. Hugh Evelyn, London.

Penubarti, Mohan, Ward, Michael, 2000. Commerce and Democracy, Center for Statistics and the Social Sciences Working Paper No. 6, University of Washington.

Pollins, Brian., 1989. Conflict, Cooperation and Commerice: The Effect of International Political Interactions on Bilateral Trade Flows. American Journal of Political Science 33, 737-761.

Ritchl, Albert, Wolf, Niklaus, 2003. Endogeneity of Currency Areas and Trade Blocs. CEPR Discussion Paper No. 4112.

Rose, Andrew, 2000. One Money, One Market: The Effect of Common Currencies on Trade. Economic Policy 15 (April), 7-33.

Thomson, Janice E., 1994. Mercenaries, Pirates, and Sovereigns: State-Building and Extraterritorial Violence in Early Modern Europe. Princeton University Press, Princeton.

Thursby, Jerry., Thursby, Marie., 1987. Bilateral Trade Flows, and Linder Hypothesis, and Exchange Risk. Review of Economics and Statistics 69 (August), 488-495.

Wareham, Tom., 2001. The Star Captains: Frigate Command in the Napoleonic Wars. Annapolis. United States Naval Institute, MD. 